\title{
CETACEAN RECORDS ALONG SÃO PAULO STATE COAST, SOUTHEASTERN BRAZIL
}

\author{
Marcos César de Oliveira Santos ${ }^{1}$; Salvatore Siciliano ${ }^{2}$; André Fabiano de Castro Vicente ${ }^{3}$; Fernando Siqueira \\ Alvarenga ${ }^{3}$; Émerson Zampirolli ${ }^{3}$; Shirley Pacheco de Souza $a^{4}$ and Andréa Maranho ${ }^{5}$ \\ ${ }^{1}$ Universidade Estadual Paulista "Júlio de Mesquita Filho" (UNESP) \\ Instituto de Biociências, Departamento de Zoologia \\ Projeto Atlantis, Laboratório de Biologia da Conservação de Cetáceos \\ (Campus Rio Claro, Av. 24-A, 1.515, Bela Vista, 13506-900 Rio Claro, SP, Brasil) \\ ${ }^{2}$ Escola Nacional de Saúde Pública/FIOCRUZ \\ Departamento de Endemias, Grupo de Estudos de Mamíferos Marinhos da Região dos Lagos, GEMM-Lagos \\ (Rua Leopoldo Bulhões 1480, sala 620, 21041-210 Manguinhos, RJ, Brasil) \\ ${ }^{3}$ Centro de Estudos sobre Encalhes de Mamíferos Marinhos (CEEMAM) \\ (Rua Prof. Torres Homem, 22, casa 4, Boqueirão, Santos, SP, 11025020, Brasil) \\ ${ }^{4}$ Instituto Terra \& Mar/Programa de Pós-Graduação em Ecologia, UNICAMP. \\ (Rua Gertrudes C. Correia, 123, São Sebastião, SP, 11600-000, Brasil) \\ ${ }^{5}$ Associação de Resgate e Reabilitação de Animais Marinhos (GREMAR) \\ (Rua Avedis Simonian, 627, Guarujá, SP, 11421-060, Brasil)
}

\begin{abstract}
The São Paulo state (SP) coast $\left(23^{\circ} 18^{\prime} \mathrm{S}, 44^{\circ} 42^{\prime} \mathrm{W} ; 25^{\circ} 14^{\prime} \mathrm{S}, 48^{\circ} 01^{\prime} \mathrm{W}\right)$ is of approximately $600 \mathrm{~km}$ in length, bordering the Western Atlantic Ocean, in southeastern Brazil. Cetacean sightings and strandings have long been observed throughout this area. Scattered data from scientific publications, skeletal remains in museums, photographs and articles from newspaper files, universities and aquaria have been organised and updated since 1993. Field investigations on strandings and sightings have also been conducted. A total of 29 cetacean species have been recorded, including 7 baleen whales (Mysticeti) and 22 toothed whales (Odontoceti), as follows: Balaenoptera physalus, B. borealis, B. edeni, B. acutorostrata, B. bonaerensis, Megaptera novaeangliae, Eubalaena australis, Physeter macrocephalus, Kogia breviceps, K. sima, Berardius arnuxii, Mesoplodon europaeus, M. mirus, Ziphius cavirostris, Orcinus orca, Feresa attenuata, Globicephala melas, G. macrorhynchus, Pseudorca crassidens, Delphinus capensis, Lagenodelphis hosei, Steno bredanensis, Tursiops truncatus, Stenella frontalis, S. longirostris, S. coeruleoalba, Lissodelphis peronii, Sotalia guianensis and Pontoporia blainvillei. Several species have been observed only once and include strays from their areas of common distribution, as well as species with known preferences for offshore distribution. Others, such as P. blainvillei and S. guianensis, are common coastal dwellers year-round. Z. cavirostris, P. crassidens and L. hosei are reported for the first time on the SP coast.
\end{abstract}

\section{RESUMO}

A costa do Estado de São Paulo (SP) $\left(23^{\circ} 18^{\prime} \mathrm{S}, 44^{\circ} 42^{\prime} \mathrm{O} ; 25^{\circ} 14^{\prime} \mathrm{S}, 48^{\circ} 01^{\prime} \mathrm{O}\right)$ apresenta aproximadamente $600 \mathrm{~km}$ de extensão voltada para o Oceano Atlântico Ocidental no sudeste do Brasil. Registros de encalhes e de avistamentos de cetáceos vêm sendo realizados ao longo desse litoral. Desde 1993, dados obtidos em literatura científica, material osteológico encontrado em museus, fotografias e artigos de arquivos de jornais, universidades e aquários foram organizados e atualizados. Investigações efetuadas em campo referentes a encalhes e avistamentos de cetáceos também foram conduzidas. Um total de 29 espécies de cetáceos foi registrado, incluindo 7 misticetos e 22 odontocetos, como indicados a seguir: Balaenoptera physalus, B. borealis, B. edeni, B. acutorostrata, B. bonaerensis, Megaptera novaeangliae, Eubalaena australis, Physeter macrocephalus, Kogia breviceps, K. sima, Berardius arnuxii, Mesoplodon europaeus, M. mirus, Ziphius cavirostris, Orcinus orca, Feresa attenuata, Globicephala melas, G. macrorhynchus, Pseudorca crassidens, Delphinus capensis, Lagenodelphis hosei, Steno bredanensis, Tursiops truncatus, Stenella frontalis, S. longirostris, S. coeruleoalba, Lissodelphis peronii, Sotalia guianensis e Pontoporia blainvillei. Algumas espécies foram observadas apenas em uma ocasião e incluem tanto vagantes de suas áreas comuns de distribuição, assim como de conhecidas áreas de distribuições preferenciais oceânicas. Outras, como P. blainvillei e $S$. guianensis, são comumente encontradas em águas rasas o ano todo. Z. cavirostris, $P$. crassidens e L. hosei são listados pela primeira vez para a costa de SP.

Descriptors: Cetaceans, Western South Atlantic, Baleen whales, Toothed whales, Strandings.

Descritores: Cetáceos, Atlântico Sul Ocidental, Misticetos, Odontocetos, Encalhes.

\section{INTRODUCTION}

The São Paulo (SP) state coast $\left(23^{\circ} 18^{\prime} \mathrm{S}, 44^{\circ}\right.$ $42^{\prime} \mathrm{W} ; 25^{\circ} 14^{\prime} \mathrm{S}, 48^{\circ} 01^{\prime} \mathrm{W}$ ) is of approximately $600 \mathrm{~km}$ in length facing the Western Atlantic Ocean, in southeastern Brazil (Fig. 1). The coast may be divided into three different sectors on the basis of their geographical characteristics. The large Cananéia estuarine system bordered by a mangrove forest is found in the southern sector (BESNARD, 1950; SCHAEFFER-NOVELLI et al., 1990). Long beaches facing the Atlantic Ocean are the common features in 
the quoted sector. The Santos bay is inserted in the central sector of the SP state coast. It is a densely populated area which hosts the largest harbor in Latin America, known as the "Porto de Santos" $\left(24^{\circ} \mathrm{S}\right)$. This port has been operating since 1892 and constitutes the main Brazilian gateway to the international market (CODESP, 1992). The northern coast is composed of several protected sandy and rocky bays usually with clearer waters than those of the central and southern sectors. A chain of mountains known as the "Serra do Mar" follows the shoreline of the entire state, influencing the seasonal variation of the coastal climate.

The continental shelf is very extensive, reaching the maximum width of $230 \mathrm{~km}$ at $24^{\circ} \mathrm{S}$ (MATSUURA, 1986). A total of 58 islands can be found at distances varying from 0.07 to $38 \mathrm{~km}$ from the shore (SMA, 1998). Local waters are influenced by the Brazil Current characterized by high temperature and salinity values, as well as by the cold Falkland/Malvinas Current, which is rich in nutrients, but with lower temperature and salinity values (EMÍLSSON, 1961; STRAMMA, 1989; CASTRO et al., 2006). The latter has greater influence in winter and spring when it is usually associated with cold fronts. Coastal water dynamics may also be seasonally influenced by the cold South Atlantic Central Water (SACW) mass (SVERDRUP et al., 1942; CASTRO et al., 2006). In late spring and summer, when a strong thermocline is observed, the SACW mass moves towards the coast into the bottom layer over the continental shelf. It retreats to the border of the continental shelf during fall and winter, when the vertical distribution of the temperature near the coastal region is homogeneous (MATSUURA, 1986). The predominant winds during fall and winter come from the south and southwest, and in spring and summer the most frequent winds come from the east and northeast (CASTRO et al., 1987). Two other important water masses are the Tropical Water (TW) mass, moving southwards with almost the same characteristics as the Brazil Current, and the Coastal Water (CW) mass, with lower salinity values and quite turbid waters based on the influence of the continental discharge to the ocean (CASTRO et al., 2006).

Cetaceans have been reported off the SP state coast since the $17^{\text {th }}$ century, when four whaling stations operated. Their names and locations were:

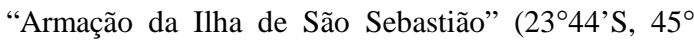
21'W), "Armação da Bertioga" (235' $\left.\mathrm{S}, 4^{\circ} 09^{\prime} \mathrm{W}\right)$,

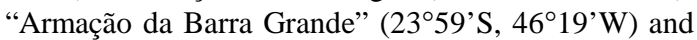

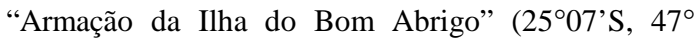
51'W) (ELLIS, 1969). The presence of "rorquals", southern right (Eubalaena australis) and sperm (Physeter macrocephalus) whales were listed as the main specimens captured. Right whales' female-calf pairs were the main target because of their coastal habits when migrating, and sperm whales were captured occasionally because of the higher prices the spermaceti oil and the amber-gris fetched in the $18^{\text {th }}$ century. Whaling declined in SP at the beginning of the $19^{\text {th }}$ century when Portugal lost the monopoly of its colony. Since then, no more whaling stations have been established on the SP state coast.

Townsend (1935) has shown the exact locations where the $19^{\text {th }}$ century American whalers made their catches of sperm, right and humpback (Megaptera novaeangliae) whales along the Brazilian coast. Sperm whales were extensively captured within the whaling ground called the "Coast of Brazil", which extended from the northeastern coast of Brazil to Uruguay. The area was usually exploited from October to March, from 1761 to 1920 . Based on the whaling charts, sperm whale captures off the SP coast occurred along the $200 \mathrm{~m}$ isobath. Southern right whales were captured from 1785 to 1913 within southern Brazilian, Uruguayan and Argentinian coastal waters, in two whaling grounds known as "Brazil" and "False Banks". Few records mention humpback whale captures along the Brazilian coast. No right and humpback whale captures were reported by American whalers on the SP coast.

Several descriptive accounts of cetaceans are known for the SP coast prior to the 1990s, when longterm studies started to be conducted. Luederwaldt (1919) mentioned the presence of dolphins in the Santos bay, moving through inner and protected waters, but giving no details of the description of the species. Right whales were documented as the target of the Brazilian Navy's training activities off the northern coast of SP state in winter and spring in the 1930s (CARVALHO, 1938 corrected by SANTOS et al., 2001a). The description of the whale lice (genus Cyamus) fauna found as ectoparasites on a dead right whale calf washed ashore at Praia Grande in October 1936 is another historical document on the seasonal presence of E. australis the SP state coast (SAWAYA, 1938). In the 1960s, records of three cetacean species were described for the coast of SP: Franciscana dolphin, Pontoporia blainvillei, incidentally captured off Santos (DE CARVALHO, 1961), Guiana dolphin, Sotalia guianensis, intentionally captured off Cananéia (DE CARVALHO, 1963), and pygmy sperm whale, Kogia breviceps, washed ashore at Santos (DE CARVALHO, 1966). An important contribution to the knowledge of cetacean records relating to the southern coast of SP was presented by Schmiegelow (1990). During a twoyear survey from 1986 to 1988 , covering ca. $91 \mathrm{~km}$ of beach on a monthly basis, the following toothed whales were observed in stranding events: $S$. guianensis (37), P. blainvillei (20); Delphinus sp. (7), 
Stenella frontalis (3), Tursiops truncatus (1), Steno bredanensis (1), K. breviceps (1), Globicephala macrorhynchus (1) and one unidentified delphinid.

Since the end of the 1990s, several research groups have been investing in cetacean research on the SP state coast, providing additional opportunities for the enhancement of our knowledge on cetacean occurrence and distribution (e.g. MONTEIRO-FILHO 1995; SANTOS et al., 2001b; ROSAS et al., 2002a;b; SANTOS et al., 2002a;b; SOUZA et al., 2005). Although most studies have been based on the recovery of stranded specimens, in several areas along the coast the monitoring of fishing fleets has been offering another possibility of recovering information from incidental cetacean captures (e.g. BERTOZZI; ZERBINI, 2002; ROSAS et al., 2002b). A survey on both published and unpublished data has been undertaken to update and organise the scattered information on cetacean records along the SP state coast. Important gas and oil reserves in offshore basins have recently been discovered off the southeastern coast of Brazil. The volume of shipping has increased, posing various threats, such as noise pollution and the risk of collisions, to cetaceans. Oil prospection is soon beginning. The present authors deem it important to assess the possible impacts resulting from such operations. An important first step would include the up-dating of the records of the occurrence and distribution of cetaceans along the coast. Moreover, the coast of SP has been exploited as a commercially important fishing ground (ROSSIWONGTSCHOWSKI, 2006). Over-exploitation has increasingly been exposing cetaceans to the risk of incidental captures, threatening coastal populations including those of several cetacean species along the coast of Brazil (SICILIANO, 1994). Gathering the baseline information on cetacean records over time and space in local waters constitutes an important task for the elaboration of management programs in the future, as cetaceans represent important sentinels of their ecosystems (MOORE, 2008).

\section{Material and Methods}

From July 1993 to March 1998, the present authors visited the main newspaper offices, museums and other institutions such as aquaria and nongovernmental organizations involved in research and conservation in order to gather evidences of cetacean records relating to the SP coast. Whenever possible, cetacean records in the form of photographs, articles in newspapers, and osteological material were recovered and the animals identified to the lowest possible taxonomic level. Sightings and strandings were also reported in situ from March 1993 to August 2009. The complete set of unpublished data is documented with photographs and/or osteological material. A review of the literature published in peer-reviewed journals was also conducted. A list of the records of each species is presented following the description of the details of each taxon. The institutions visited with the appropriate abbreviations used in the text are listed in APPENDIX I. The exact locations of the main coastal cities and islands mentioned in this manuscript are shown in Figure 1.

\section{RESULTS}

Twenty-nine cetacean species have been recorded off the SP state coast: 7 baleen whales (Mysticeti) and 22 toothed whales (Odontoceti). These species are here listed according to the nomenclature of Jefferson et al. (2008): Mysticeti - fin whale, Balaenoptera physalus; sei whalei, B. borealis; Bryde's whale, $B$. edeni; common minke whale, $B$. acutorostrata; Antarctic minke whale, B. bonaerensis; humpback whale, Megaptera novaeangliae; southern right whale, Eubalaena australis; Odontoceti - sperm whale, Physeter macrocephalus; pygmy sperm whale, Kogia breviceps; dwarf sperm whale, K. sima; Arnoux's beaked whale, Berardius arnuxii; Gervais' beaked whale, Mesoplodon europaeus; True's beaked whale, M. mirus; Cuvier's beaked whale, Ziphius cavirostris; southern right-whale dolphin, Lissodelphis peronii; killer whale, Orcinus orca; pygmy killer whale, Feresa attenuata; false killer whale, Pseudorca crassidens; short-finned pilot whale, Globicephala macrorhynchus; long-finned pilot whale, G. melas; Fraser's dolphin, Lagenodelphis hosei; long-beaked common dolphin, Delphinus capensis; rough-toothed dolphin, Steno bredanensis; bottlenose dolphin, Tursiops truncatus; Atlantic spotted dolphin, Stenella frontalis; striped dolphin, S. coeruleoalba; spinner dolphin, S. longirostris; Guiana dolphin, Sotalia guianensis and Franciscana dolphin, Pontoporia blainvillei.

\section{Species Accounts}

Suborder Mysticeti

Balaenopteridae

- Balaenoptera physalus (Linnaeus, 1758): The vertebrate collection of the MZUSP contains fin whales' tympanic bullae collected in São Sebastião by Garbe in 1905 (MZUSP-3282) and in Santos by Von R. Ihering in 1916 (MZUSP-3285). The only known confirmed stranding was observed on 08 September 1941, when a long fin whale of $c a .20 \mathrm{~m}$ in length was found dead at Peruíbe (cited in ZERBINI et al., 1997). Its complete skeleton without a collection number is on exhibition at the MIPS (Fig. 2).

- Balaenoptera borealis Lesson, 1828: One confirmed stranding occurred on 18 August 1988, when a male 
sei whale was found dead on the Praia da Boracéia, Bertioga (cited in ZERBINI et al., 1997). It had an estimated total length of $12 \mathrm{~m}$. It was buried and lost. Photographs taken by local onlookers allowed the precise identification of this specimen.

- Balaenoptera edeni Anderson, 1879: In recent years, opportunistic sightings have been showing that Bryde's whales are commonly found in summer and fall around the area associated with several coastal islands such as Lage de Santos, Alcatrazes archipelago, Queimada Grande and Vitória (see ZERBINI et al., 1997; SICILIANO et al., 2004). Twelve strandings observed between 1972 and 2003 were listed by SICILIANO et al. (2004). Six additional strandings are presented in Table 1, which includes the first record of a calf on the SP coast (Fig. $3)$.

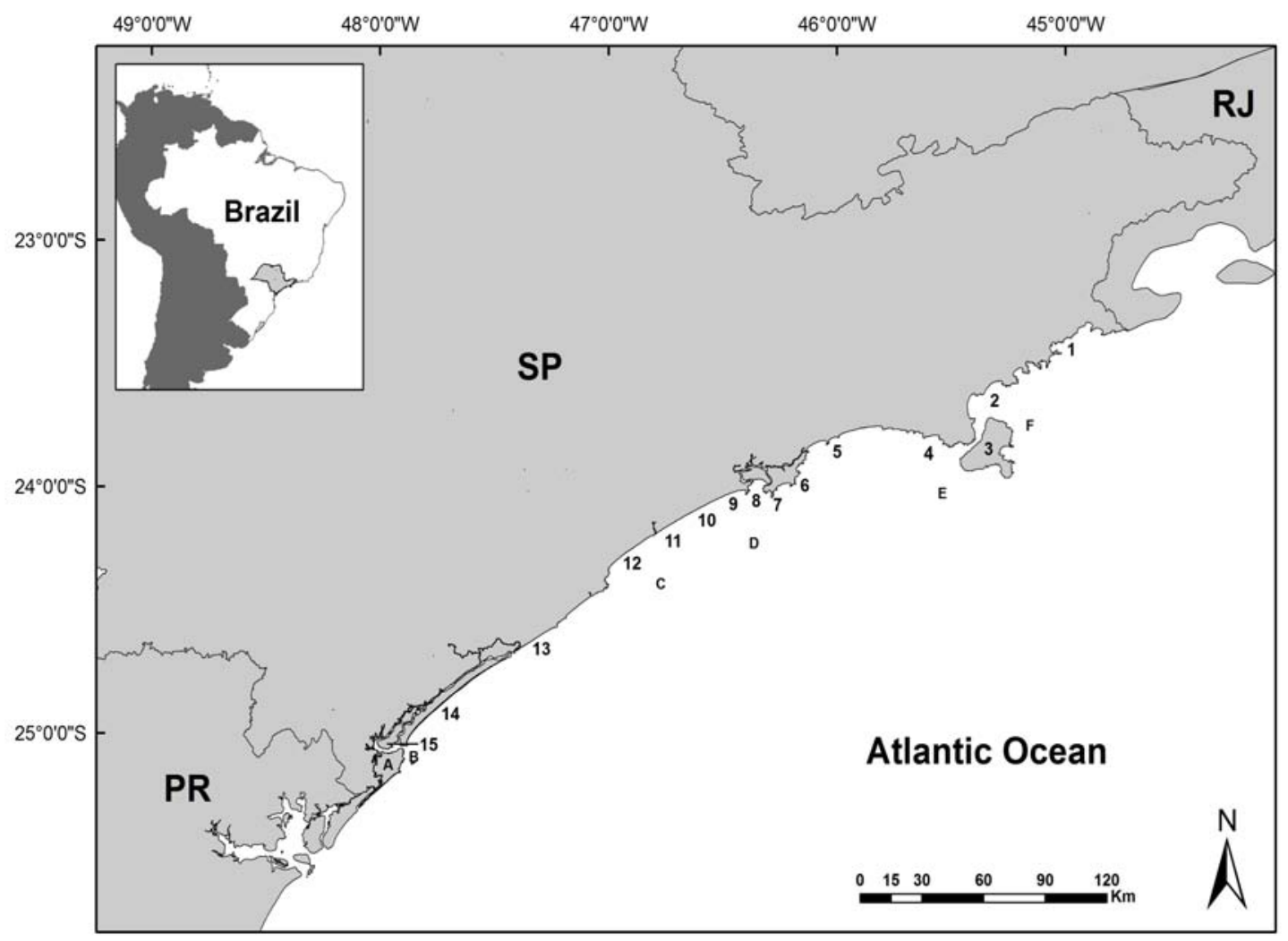

Fig. 1. São Paulo (SP) state coast located in southeastern Brazil. Main locations where cetaceans have been found and quoted in the manuscript are: (1) Ubatuba, (2) Caraguatatuba, (3) Ilhabela, (4) São Sebastião, (5) Bertioga, (6) Santos, (7) São Vicente, (8) Guarujá, (9) Mongaguá, (10) Itanhaém, (11) Praia Grande, (12) Peruíbe, (13) Iguape, (14) Ilha Comprida, (15) Cananéia, (A) Ilha do Cardoso, (B) Ilha do Bom Abrigo, (C) Ilha da Queimada Grande, (D) Lage de Santos, (E) Alcatrazes archipelago, (F) Ilha Vitória. Cities are identified by number and islands by capital letters. PR means Paraná state and RJ Rio de Janeiro state. 
- Balaenoptera acutorostrata Lacépède, 1804 and $B$. bonaerensis Burmeister, 1867: A total of 16 stranding records of minke whales observed from 1986 to 2008 is presented in Table 2 . It was possible to identify 5 Antarctic minke whales (B. bonaerensis) and 6 common minke whales (B. acutorostrata) (Fig. 4) based on color patterns and/or cranial features. The advanced state of decomposition, together with the fact that several individuals were buried and not recovered, did not allow the identification of the remaining specimens.

- Megaptera novaeangliae (Borowski, 1781): A total of 15 strandings of humpback whales were observed and registered between 1984 and 2009 (Table 3). Most records $(80 \%)$ were of immature specimens (males of

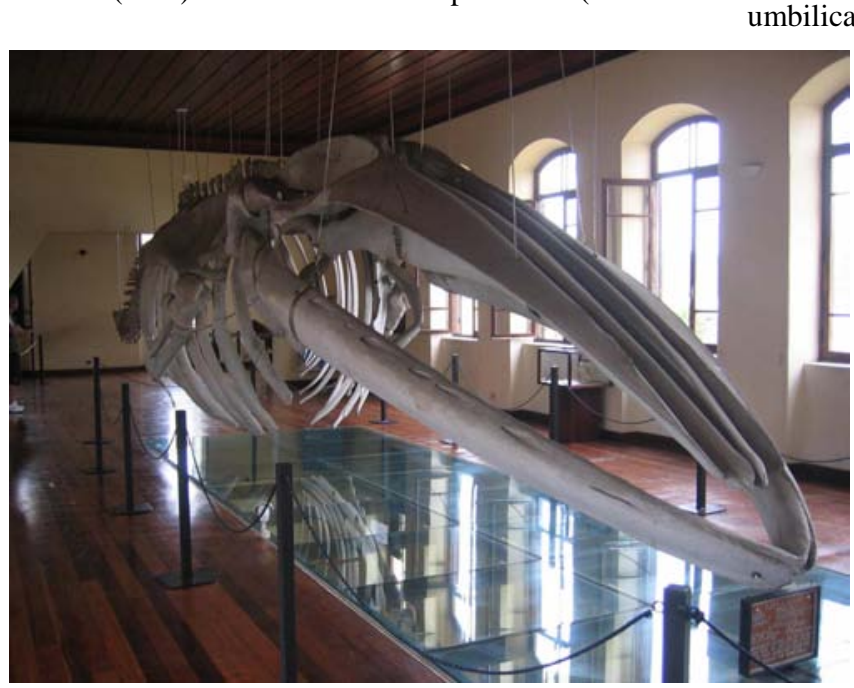

up to $11 \mathrm{~m}$ in length and females of up to $12 \mathrm{~m}$, according to Jefferson et al., 2008).

\section{Balaenidae}

- Eubalaena australis Desmoulins, 1822: Two right whale tympanic bullae (MZUSP-2758 and 19837), collected in Iguape in 1902, were reported by Castello and Pinedo (1979). Sightings and strandings were recently updated by Lodi et al. (1996) and Santos et al. (2001a). A total of eight strandings were reported between 1936 and 2000 (see updated list in Santos et al., 2001a). Another stranding occurred on 15 August 2007, of a $4.5 \mathrm{~m}$ long male found at Itanhaém (CEEMAM-319). Most stranding records (67\%) related to calves, three occurrences of which were related to individuals presenting vestiges of the umbilical cord.
Fig. 2. An 18-m long skeleton of a fin whale (Balaenoptera physalus) found washed ashore at Peruíbe in 1941. It is on exhibition at Museu do Instituto de Pesca, Santos. Photo: Marcos Santos.

Table 1. Stranding records of Bryde's whales, Balaenoptera edeni, on SP state coast from 2005 to 2009. All specimens were buried and none recovered. TL means "Total Length" given in metres (m). "U" means unknown.

\begin{tabular}{cccccc}
\hline \hline Field Number & Date & Location & TL $(\mathrm{m})$ & Sex & Source/Destiny \\
\hline SOSMM-151 & 13-oct-2005 & São Sebastião & 12.0 & $\mathrm{M}$ & Present study/Buried; not recovered \\
SOSMM-165 & 23-oct-2006 & São Sebastião & 12.8 & $\mathrm{M}$ & Present study/Buried; not recovered \\
CEEMAM-307 & 20-jul-2007 & Peruíbe & 12.0 & $\mathrm{U}$ & Present study/Buried; not recovered \\
CEEMAM-318 & 12-aug-2007 & Praia Grande & 4.5 & F & Present study/Buried; not recovered \\
C.01.4.1.78- 8 & 08-mar-2008 & Guarujá & 8.4 & M & Present study/Buried; not recovered \\
CEEMAM-351 & 25-jul-2009 & Guarujá & 13.0 & M & Present study/Buried; not recovered
\end{tabular}


Fig. 3. A $4.5 \mathrm{~m}$ long female Bryde's whale (Balaenoptera edeni) washed ashore on Praia Grande on 12 August 2007 (CEEMAM-318) Photo: Andréa Maranho.

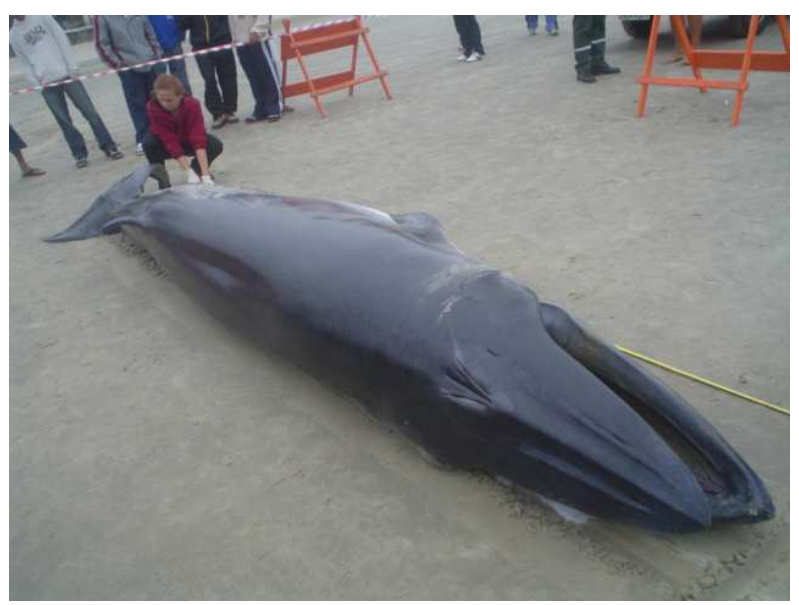

Table 2. Minke whale strandings on SP state coast. Antarctic (B. bonaerensis) and common ( $B$. acutorostrata) minke whales are represented by "A" and "C", respectively. TL means "Total Length" given in metres (m), "U" unknown and "Sp." species.

\begin{tabular}{|c|c|c|c|c|c|c|}
\hline Field Number & Date & Location & $\begin{array}{l}\mathrm{TL} \\
(\mathrm{m})\end{array}$ & Sex & Sp. & Source/Destiny \\
\hline \multirow[t]{2}{*}{-} & 05-Sep-1986 & Ilha Comprida & 5.0 & $\mathrm{U}$ & $\mathrm{C}$ & Cited in Zerbini et al. (1996) \\
\hline & & & & & & Buried; not recovered \\
\hline \multirow[t]{2}{*}{-} & 12-Oct-1989 & Ubatuba & 6.0 & $\mathrm{~F}$ & $\mathrm{C}$ & Cited in Zerbini et al. (1996) \\
\hline & & & & & & $\begin{array}{l}\text { Photographs of skull - not } \\
\text { recovered }\end{array}$ \\
\hline \multirow[t]{2}{*}{-} & 03-Dec-1990 & Bertioga & 8.5 & $\mathrm{U}$ & A & Cited in Zerbini et al. (1997) \\
\hline & & & & & & $\begin{array}{c}\text { Complete skeleton in SESC } \\
\text { Bertioga }\end{array}$ \\
\hline- & 10-Oct-1990 & Guarujá & 8.0 & $\mathrm{U}$ & A & Complete skeleton in the MMS \\
\hline- & 05-Nov-1992 & Itanhaém & 5.0 & M & $\mathrm{C}$ & $\begin{array}{l}\text { TS; Cited in Zerbini et al. } \\
\text { (1996) }\end{array}$ \\
\hline- & 22-May-1994 & São Sebastião & 5.0 & $\mathrm{U}$ & $\mathrm{U}$ & $\begin{array}{l}\text { FUNDAMAR - part of the } \\
\text { skull }\end{array}$ \\
\hline PA-88 & 11-Aug-1997 & Ilha do Cardoso & 5.0 & $\mathrm{U}$ & $\mathrm{U}$ & $\begin{array}{l}\text { Part of the skull in the PA } \\
\text { collection }\end{array}$ \\
\hline CEEMAM-016 & 31-Oct-1997 & Santos & 4.0 & $\mathrm{U}$ & $\mathrm{C}$ & Skull in the MIPS collection \\
\hline CEEMAM-017 $\star$ & 17-Nov-1997 & Bertioga & 3.5 & $\mathrm{U}$ & A & Live stranding; released alive \\
\hline CEEMAM-018 $\star$ & 05-Dec-1997 & Guarujá & 3.5 & M & A & Live stranding; released alive \\
\hline CEEMAM-042 & 23-Sep-1998 & Mongaguá & 6.6 & M & $\mathrm{U}$ & Buried; not recovered \\
\hline CEEMAM-159 & 27-Jul-2002 & Santos & 5.0 & $\mathrm{U}$ & $\mathrm{U}$ & Skull in the MIPS collection \\
\hline SOSMM-104 & 12-Sep-2002 & Ilhabela & 3.0 & M & $\mathrm{C}$ & Buried; not recovered \\
\hline CEEMAM-175 & 10-Nov-2002 & Praia Grande & 3.8 & $\mathrm{~F}$ & A & Buried; not recovered \\
\hline CEEMAM-274 & 27-Oct-2006 & Praia Grande & 6.0 & M & $\mathrm{U}$ & Buried; not recovered \\
\hline CEEMAM-316 & 07-Aug-2007 & Guarujá & 2.2 & $\mathrm{~F}$ & $\mathrm{C}$ & $\begin{array}{c}\text { Live stranding, Buried after } \\
\text { death }\end{array}$ \\
\hline
\end{tabular}

$\star$ Live strandings of the same individual not found after second release. 


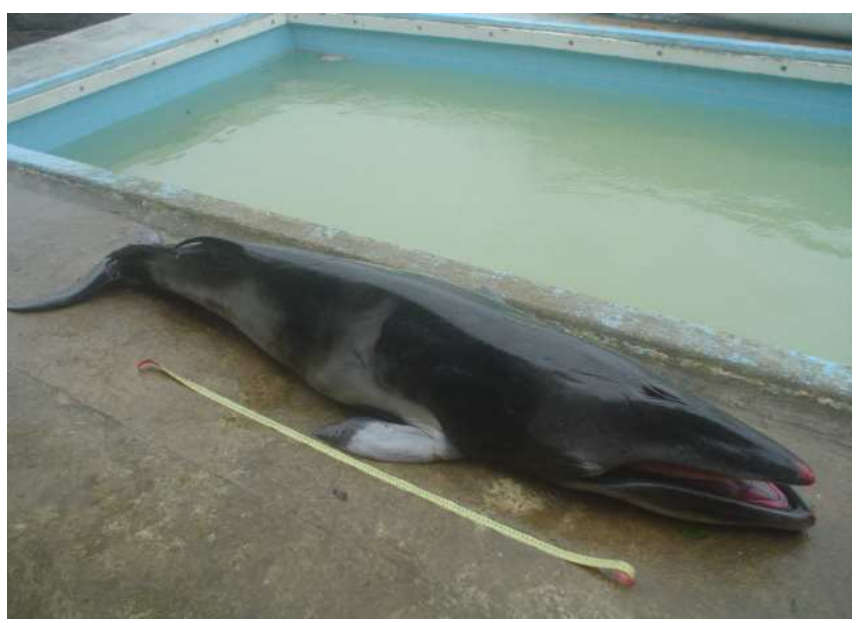

Fig. 4. A $2.2 \mathrm{~m}$ long female common minke whale (Balaenoptera acutorostrata) washed ashore at Guarujá on 07 August 2007 (CEEMAM-316). Photo: Andréa Maranho.

Table 3. Stranding records of humpback whales (Megaptera novaeangliae) on SP state coast from 1984 to 2008. TL means "Total Length" given in metres (m), "U" unknown.

\begin{tabular}{cccccc}
\hline \hline Field Number & Date & Location & TL $(\mathrm{m})$ & Sex & Source/Destiny \\
\hline- & 01-May-1984 & Praia Grande & 7.0 & $\mathrm{M}$ & FSP \\
- & 19-Feb-1988 & Praia Grande & 6.0 & $\mathrm{U}$ & TS \\
SOSMM-24 & 14-Dec-1995 & São Sebastião & 7.2 & $\mathrm{~F}$ & FUNDAMAR collection \\
- & 09-Oct-1997 & Ilha do Cardoso & 7.0 & $\mathrm{M}$ & PEIC on exhibition \\
SOSMM-48 & 29-Aug-1998 & Ilhabela & 6.0 & $\mathrm{U}$ & Buried; not recovered \\
SOSMM-78 & 03-Nov-2000 & Ubatuba & 11.0 & $\mathrm{M}$ & Buried; not recovered \\
SOSMM-79 & 24-Nov-2000 & São Sebastião & 16.0 & $\mathrm{~F}$ & On exhibition inUbatuba \\
CEEMAM-143 & 14-Mar-2002 & Bertioga & 6.5 & $\mathrm{U}$ & Buried; not recovered \\
SOSMM-141 & 02-Dec-2004 & São Sebastião & 6.5 & $\mathrm{M}$ & Buried; not recovered \\
SOSMM-152 & 17-Oct-2005 & São Sebastião & 9.5 & $\mathrm{M}$ & Buried; not recovered \\
CEEMAM-272 & 12-Oct-2006 & Itanhaém & 7.0 & $\mathrm{M}$ & MIPS collection \\
- & 06-Aug-2007 & Guarujá & 12.0 & $\mathrm{M}$ & Buried; not recovered \\
SOSMM-177 & 01-Nov-2007 & Ilhabela & 3.7 & $\mathrm{M}$ & Buried; not recovered \\
CEEMAM-342 & 09-Jul-2008 & Praia Grande & 7.2 & $\mathrm{~F}$ & Buried; not recovered \\
C.02.1.0.112 09 & 11-Apr-2009 & Guarujá & 10.0 & $\mathrm{~F}$ & Buried; not recovered \\
\hline
\end{tabular}

Table 4. Stranding records of sperm whales, Physeter macrocephalus, on SP state coast from 1967 to 2008. All specimens were buried and none recovered. TL means "Total Length" given in metres (m), "U" unknown.

\begin{tabular}{|c|c|c|c|c|c|}
\hline Field Number & Date & Location & $\mathrm{TL}(\mathrm{m})$ & Sex & Source/Destiny \\
\hline- & 15-May-1967 & Praia Grande & 15.0 & M & FSP/Buried; not recovered \\
\hline- & 25-May-1991* & São Sebastião & 9.5 & $\mathrm{U}$ & AE/Buried; not recovered \\
\hline- & 05-Oct-1991 ${ }^{*}$ & Peruíbe & 15.0 & M & MMS/Buried; not recovered \\
\hline PA-107 & 03-Mar-1998* & Ilha Comprida & 10.0 & $\mathrm{U}$ & Buried; not recovered \\
\hline CEEMAM-213 & 17-Dec-2003 & Mongaguá & 17.0 & M & Buried; not recovered \\
\hline CEEMAM-220 & 05-Jun-2006 & Iguape & 11.0 & M & Buried; not recovered \\
\hline
\end{tabular}

*Cited in RAMOS et al. (2001). 
Suborder Odontoceti

Physeteridae

- Physeter macrocephalus Linnaeus, 1758: Six strandings of sperm whales were recorded between 1967 and 2006 (Table 4). Those observed in May 1967 and May 1991 were related to live strandings followed by the death of both specimens. On 30 June 1986, a long lower jaw, of $c a .3 .5 \mathrm{~m}$ in length, of a sperm whale was collected by a small motor-powered fishing boat. The boat was operating close to the Ilha do Bom Abrigo, one of the four whaling stations of the $18^{\text {th }}$ century. The jaw without any collection number is on exhibition at the MMS.

- Kogia breviceps (De Blainville, 1838): Four records of the pygmy sperm whale are presented. De Carvalho (1966) described a pregnant female specimen found dead at Santos on 08 0ctober 1965, with notes on its external measurements and parasites. The complete skeleton of the specimen (MZUSP-10597) and the fetus preserved in formalin (MZUSP-18927) were recovered. In January 1988, an adult female was found beached on Praia do Marujá, Ilha do Cardoso (SCHMIEGELOW, 1990), but no further data or skeletal remains were collected. A $288 \mathrm{~cm}$ long pregnant female was found washed ashore at Santos on 11 July 2000 (Fig. 5) (CEEMAM-090). Its complete skeleton and the fetus preserved in formalin are deposited in the MIPS collection. Another stranding of a $300 \mathrm{~cm}$ long female was reported at
Peruibe on 30 September 2005 (CEEMAM-246). The specimen was buried and not recovered.

- Kogia sima Owen, 1866: Four stranding records of the dwarf sperm whale are known. On 27 February 1998 a $223 \mathrm{~cm}$ long pregnant female was found stranded on Praia Grande (CEEMAM-020). Its complete skeleton and the fetus preserved in formalin are deposited in the MIPS collection. On 25 June 2002 , a $230 \mathrm{~cm}$ long male was found washed ashore on/at São Sebastião (SOSMM-97). Its skeleton was buried but not recovered. A $210 \mathrm{~cm}$ long male was found dead at Itanhaém on 7 December 2007 (CEEMAM-332). Its complete skeleton is also deposited in the MIPS collection. On 04 July 2009 a $183 \mathrm{~cm}$ long female was found dead at Guarujá (C.05.1.2.114 - 09).

Ziphiidae

- Berardius arnuxii Duvernoy, 1851: The only known occurrence of this species on the SP coast was reported by Siciliano; Santos (2003). On 04 August 1993, a $7 \mathrm{~m}$ long Arnoux beaked whale in an advanced state of decomposition was observed floating in São Sebastião coastal waters. It was buried and recovered six months later when the correct identification based on cranial features was made. The whale's nearly complete skeleton, without a collection number, is on exhibition at the Balneário dos Trabalhadores, São Sebastião.

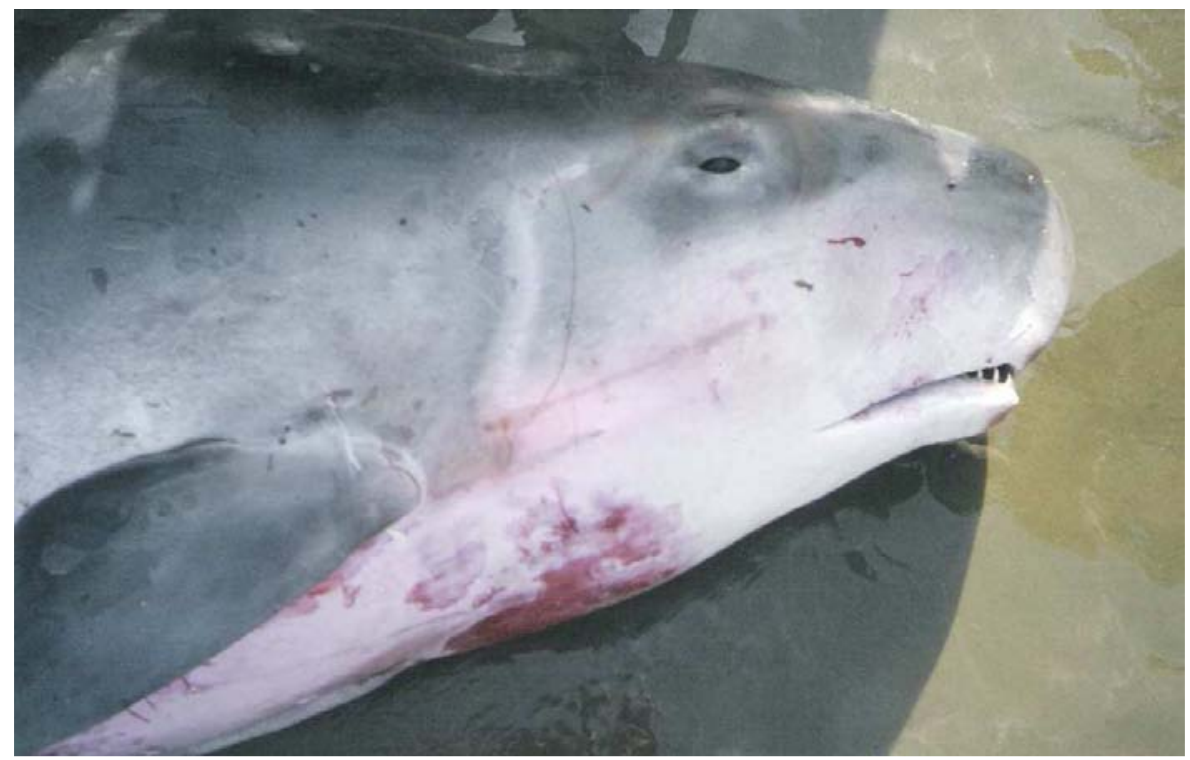

Fig. 5. Pregnant pygmy sperm whale (Kogia breviceps) of $288 \mathrm{~cm}$ washed ashore at Santos on 11 July 2000 (CEEMAM-090). Photo: André Vicente. 
- Mesoplodon europaeus (Gervais, 1855): The first occurrence of the Gervais' beaked whale on the Brazilian coast was observed on 10 August 2001 at São Vicente (SANTOS et al., 2003). A ca. $390 \mathrm{~cm}$ long specimen was found on a rocky shore in an advanced state of decomposition. Its skull is deposited in the MIPS collection (CEEMAM-127).

- Mesoplodon mirus TRUE, 1913: On 4 May 2004 the only known stranding of a True's beaked whale was reported on the coast of SP (SOUZA et al., 2005). It was the live stranding of a $4.6 \mathrm{~m}$ long male which died several hours later on the northern coast of São Sebastião Island. The complete skeleton is deposited in the ITM collection (SOSMM-130).

- Ziphius cavirostris G. Cuvier, 1823: On 30 August 1948 a 6.2 m long female Cuvier's beaked whale was landed at Guarujá. It was incidentally captured during fishing operations and sold to a fertilizer company. It was identified by Carvalho (1969) as a probable $Z$. cavirostris specimen and confirmed as such by Pinedo et al. (2001). A probable occurrence was recorded on 11 September 1974 (TS files). A specimen of ca. $5 \mathrm{~m}$ in length was stranded alive on Praia Grande. Although local people tried to push it back into the sea, the specimen died several hours later. After its death, local fishermen consumed its meat and no skeletal remains were recovered. Only two photographs are available, but give no clues as to its species identity.

\section{Delphinidae}

- Lissodelphis peronii (Lacépède, 1804): The only known occurrence of a southern right-whale dolphin on the Brazilian coast was recorded on 28 May 1994, when a $186 \mathrm{~cm}$ long male was stranded on Praia da Juréia (MARTUSCELLI et al., 1995). Its complete skeleton was deposited in the MZUSP collection (MZUSP-57897).

- Orcinus orca (Linnaeus, 1758): Although no strandings of killer whales have been observed, several sightings have been reported since the 1980s. In September 1988, during a routine trip of the CETESB research vessel in waters close to São Sebastião, one juvenile killer whale followed the ship for about 10 minutes (Fig. 6). On 05 February 1994, another sighting, this time of two adult orcas was reported in Ubatuba coastal waters by the staff of the Projeto TAMAR. On 22 February 1996, at least 10 killer whales were observed engaged in feeding activities on the northern coast of SP state (LODI; HETZEL, 1998). From 2005 to 2008, three sightings of the same male killer whale, recognizable by a few distinct notches on its dorsal fin, were presented by Santos and Da Silva (2009). All the sightings quoted occurred in shallow waters of less than $30 \mathrm{~m}$ depth.

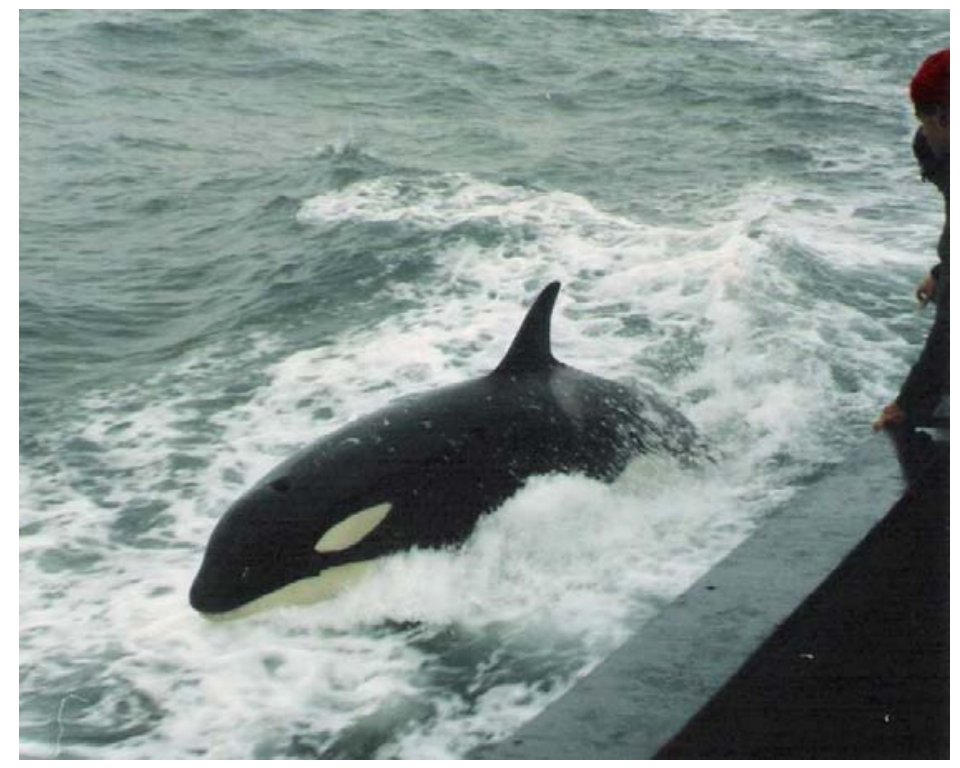

Fig. 6. A juvenile killer whale (Orcinus orca) riding close to a research vessel from CETESB in shallow waters of São Sebastião in September 1988. Photo: Sérgio Pompéia. 
- Feresa attenuata Gray, 1874: The first recorded occurrence of the pygmy killer whale on the Brazilian coast was reported by Zerbini; Santos (1997). A female pygmy killer whale was stranded alive at Mongaguá on 03 April 1994. It was pushed back into the sea by local people, but was found dead the next day on the same beach. It had an estimated total length of about $230 \mathrm{~cm}$. Its complete skeleton is on exhibition without a collection number at the MMS. Details of its osteology, pathology and stomach content analysis can be found in Zerbini; Santos (1997).

- Pseudorca crassidens (Owen, 1846): On 31 May 2005 the only known stranding of a false killer whale on the SP coast was observed at Bertioga (Fig. 7) (CEEMAM-219). The complete skeleton of this $4.3 \mathrm{~m}$ long male is on exhibition at the MIPS.

- Globicephala macrorhynchus Gray, 1846: The only occurrence of the long-finned pilot whale to be reported in SP state was recorded by Schmiegelow; Paiva Filho (1989), based on a skull found on Ilha Comprida in December 1986. It was deposited in the MZUSP collection (MZUSP-27645).

- Globicephala melas (TRAILL, 1809): In 1920, Luederwaldt collected a skull of the short-finned pilot whale on Ilha Comprida (cited in DE CARVALHO, 1975; SCHMIEGELOW; PAIVA FILHO, 1989), later deposited in the MZUSP collection (MZUSP-4192). It represents the only known account of this species in SP.

- Lagenodelphis hosei Fraser, 1956: The first known record of a Fraser's dolphin on the SP coast relates to a $200 \mathrm{~cm}$ long specimen found in an advanced state of decomposition on Praia Grande, on 12 September
1999. Its skull is deposited in the MIPS collection (CEEMAM-072). Another stranding was observed on 15 November 2007 in Ilha do Cardoso State Park. A $210 \mathrm{~cm}$ long female was found by local people. The recovered skull is deposited in the PA collection (PA282).

- Delphinus capensis Gray, 1828: Sixteen strandings presented in Santos et al. (2002a) were related to Delphinus capensis, in accordance with the rostral ratio evaluation proposed by Heyning; Perrin (1994). A recent updated review of sightings and strandings of Delphinus on the coast of Brazil (see TAVARES et al., 2010) adds several records to those related to the SP coast. Sightings are usually reported on SCUBA diving cruises to coastal islands such as Vitória, Alcatrazes and Queimada Grande.

- Steno bredanensis (Lesson, 1828): Strandings of rough-toothed dolphins have been reported all along the SP coast (Table 5). One of these records was based on the analysis of osteological material collected by J.M.M. Schmiegelow on Ilha Comprida on 22 October 1987 (SCHMIEGELOW, 1990). The skeleton was deposited in the MZUSP collection and mistakenly identified as that of a Tursiops gephyreus (=truncatus). On 02 January 1997 a rough-toothed dolphin calf was found stranded alive at Santos (AE). It was a $124 \mathrm{~cm}$ long female calf which was carried to the AMS. After ten days of routine contact with volunteers for rehabilitation purposes, the calf died (TS). On 28 December 1998, a $250 \mathrm{~cm}$ long male was stranded alive at Guarujá and after several hours spent with volunteers in shallow waters (Fig. 8), it was successfully returned to the sea (CEEMAM-055).

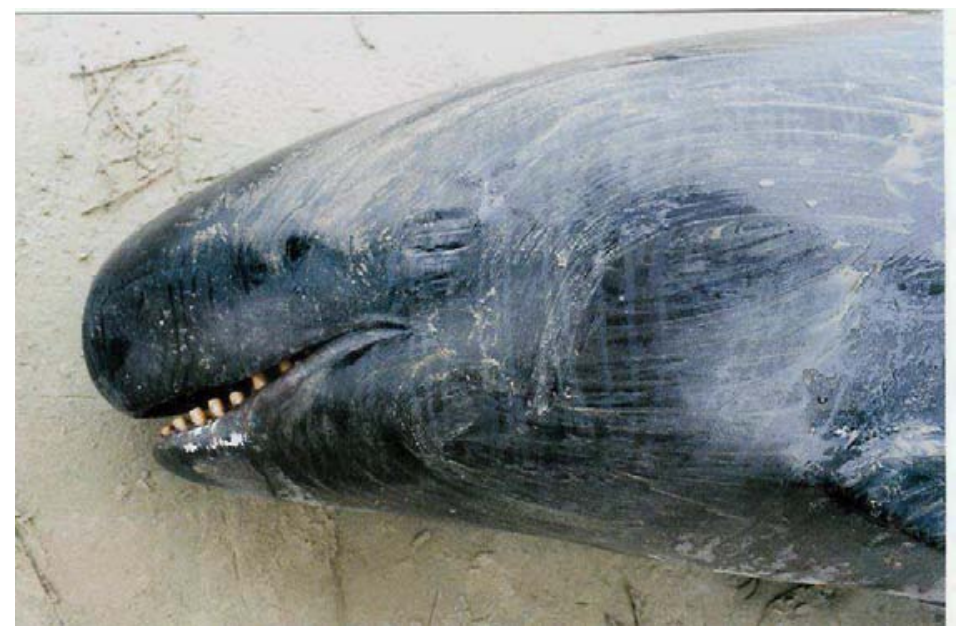

Fig. 7. A $4.3 \mathrm{~m}$ long male false killer (Pseudorca crassidens) found dead at Bertioga on 31 May 2005 (CEEMAM-219). Photo: Roberta Cassaniga. 
Table 5. Stranding records of rough-toothed dolphins (Steno bredanensis) on SP state coast from 1984 to 2008 . TL means "Total Length" given in cm, "U" unknown.

\begin{tabular}{cccccc}
\hline \hline Field Number & Date & Location & TL $(\mathrm{cm})$ & Sex & Source/Destiny \\
\hline MZUSP 27625 & 22-Oct-1987 & Ilha Comprida & 254 & $\mathrm{U}$ & Schmiegelow (1990) \\
SOSMM-010 & 16-Sep-1994 & São Sebastião & 249 & $\mathrm{~F}$ & Complete skeleton - FUNDAMAR \\
SOSMM-017 & 07-Mar-1995 & São Sebastião & 246 & $\mathrm{M}$ & Complete skeleton - FUNDAMAR \\
PA-043 & 29-Sep-1996 & Ilha Comprida & - & $\mathrm{U}$ & Skull in the PA collection \\
SOSMM-040 & 26-Mar-1998 & São Sebastião & 215 & $\mathrm{~F}$ & Complete skeleton - FUNDAMAR \\
PA-108 & 01-May-1998 & Ilha Comprida & - & $\mathrm{U}$ & Skull in the PA collection \\
CEEMAM-055 & 20-Dec-1998 & Guarujá & 250 & $\mathrm{M}$ & Live stranding, released alive \\
CEEMAM-108 & 28-Aug-2000 & Praia Grande & 263 & $\mathrm{M}$ & Skull in the MIPS collection \\
CEEMAM-133 & 28-Jan-2001 & Santos & 250 & $\mathrm{M}$ & Skull in the MIPS collection \\
SOSMM-090 & 15-Aug-2001 & São Sebastião & 267 & $\mathrm{U}$ & Complete skeleton - FUNDAMAR \\
SOSMM-133 & 21-Jun-2004 & São Sebastião & 262 & $\mathrm{~F}$ & Buried; not recovered \\
\hline
\end{tabular}

- Tursiops truncatus (Montagu, 1821): Forty unpublished stranding records of bottlenose dolphins are listed in Table 6 . A nearly complete $T$. truncatus skeleton was collected on the Praia da Juréia on 12 July 1986 (MZUSP-20382), but no further information was available. A male bottlenose dolphin, captured in Santa Catarina state $\left(27^{\circ} \mathrm{S}\right)$ in 1983 for display at a small facility in São Vicente, was sighted in May 1994 in the southern waters of the SP coast after its release at the selfsame spot at which it was captured in April 1993. It was freeze-branded on both sides of its dorsal fin for tracking purposes. Subsequently it was observed in Cananéia estuarine waters $\left(25^{\circ} \mathrm{S}\right)$ for at least two days (Fig. 9) and then it moved northwards to Santos $\left(24^{\circ} \mathrm{S}\right)$, where it was frequently seen interacting with swimmers for three months. It was last seen in Paraná state coastal waters $\left(26^{\circ} \mathrm{S}\right)$ and has not been reported since October 1994. From 1993 to 1995, the first known account of a lone and sociable dolphin in Brazilian waters was reported on the northern coast of SP (SANTOS, 1997). A human fatality was the result of unsupervised interactions between the $2.6 \mathrm{~m}$ long male dolphin and swimmers at Caraguatatuba on 08 December 1994. The animal has not been seen since August 1995. The second account of a lone and sociable bottlenose dolphin in Brazil occurred in 2003 when a $318 \mathrm{~cm}$ long female was continuously sighted swimming with bathers at Ubatuba and Bertioga. It was found dead in São Vicente (CEEMAM-197; see Table 6) after moving ca. $250 \mathrm{~km}$ southwards from the spot at which it was first sighted. The body showed clear evidences of trauma provoked by collision with a boat. 
Table 6. Stranding records of bottlenose dolphins, Tursiops truncatus, on SP state coast from 1994 to 2008. TL means "Total Length" given in cm, "U" unknown.

\begin{tabular}{|c|c|c|c|c|c|}
\hline Field Number & Date & Location & $\mathrm{TL}(\mathrm{cm})$ & Sex & Source/Destiny \\
\hline SOSMM-05 & 19-Aug-1994 & Ilhabela & - & $\mathrm{U}$ & Skull in the SOSMM collection \\
\hline SOSMM-06 & 25-Aug-1994 & São Sebastião & - & $\mathrm{U}$ & Skull in the FUNDAMAR collection \\
\hline SOSMM-08 & 09-Sep-1994 & São Sebastião & 255 & $\mathrm{U}$ & Skull in the FUNDAMAR collection \\
\hline SOSMM-018 & 26-Aug-1995 & São Sebastião & 260 & $\mathrm{U}$ & Buried; not recovered \\
\hline SOSMM-023 & 04-Dec-1995 & São Sebastião & 258 & $\mathrm{U}$ & Buried; not recovered \\
\hline PA-036 & 18-Sep-1996 & Ilha do Cardoso & 193 & $\mathrm{U}$ & Skull in the PA collection \\
\hline PA- 040 & 29-Sep-1996 & Ilha Comprida & 170 & $\mathrm{U}$ & Skull in the PA collection \\
\hline PA-043 & 29-Sep-1996 & Ilha Comprida & - & $\mathrm{U}$ & Skull in the PA collection \\
\hline PA- 060 & 28-Nov-1996 & Ilha Comprida & 312 & $\mathrm{U}$ & Skull in the PA collection \\
\hline PA-061 & 28-Nov-1996 & Ilha Comprida & 251 & $\mathrm{~F}$ & Skull in the PA collection \\
\hline PA-062 & 28-Nov-1996 & Ilha Comprida & - & $\mathrm{U}$ & Skull in the PA collection \\
\hline PA-063 & 28-Nov-1996 & Ilha Comprida & 252 & $\mathrm{~F}$ & Skull in the PA collection \\
\hline PA-065 & 29-Dec-1996 & Ilha Comprida & - & $\mathrm{U}$ & Skull in the PA collection \\
\hline PA-071 & 28-Feb-1997 & Ilha Comprida & 235 & M & Skull in the PA collection \\
\hline PA-074 & 25-Mar-1997 & Ilha Comprida & 300 & $\mathrm{~F}$ & Skull in the PA collection \\
\hline CEEMAM-003 & 04-May-1997 & São Vicente & 315 & $\mathrm{~F}$ & Skull in the MIPS collection \\
\hline CEEMAM-005 & 18-May-1997 & Mongaguá & 264 & $\mathrm{~F}$ & Skull in the MIPS collection \\
\hline CEEMAM-008 & 24-May-1997 & Itanhaém & 217 & $\mathrm{U}$ & Buried; not recovered \\
\hline SOSMM-033 & 11-Jul-1997 & São Sebastião & - & $\mathrm{U}$ & Buried; not recovered \\
\hline SOSMM-035 & 24-Jul-1997 & Ilhabela & $240+$ & $\mathrm{U}$ & Buried; not recovered \\
\hline CEEMAM-010 & 25-Jul-1997 & Itanhaém & $\begin{array}{c}240+ \\
163\end{array}$ & M & Buried; not recovered \\
\hline CEEMAM-011 & 15-Aug-1997 & São Vicente & 210 & $\mathrm{U}$ & Skull in the MIPS collection \\
\hline PA-093 & 30-Sep-1997 & Ilha Comprida & - & $\mathrm{U}$ & Skull in the PA collection \\
\hline SOSMM-043 & 05-Jun-1998 & São Sebastião & $240+$ & $\mathrm{U}$ & Buried; not recovered \\
\hline SOSMM-046 & 27-Jul-1998 & Ilhabela & $180+$ & M & Buried; not recovered \\
\hline CEEMAM-054 & 19-Dec-1998 & Peruíbe & 290 & $\mathrm{U}$ & Skull in the MIPS collection \\
\hline SOSMM-053 & 05-Jun-1999 & São Sebastião & 330 & M & Skull in the FUNDAMAR collection \\
\hline CEEMAM-123 & 14-Mar-2001 & Santos & 300 & $\mathrm{U}$ & Buried; not recovered \\
\hline SOSMM-085 & 06-May-2001 & São Sebastião & 243 & $\mathrm{U}$ & Buried; not recovered \\
\hline SOSMM-112 & $23-F e b-2003$ & São Sebastião & $185+$ & $\mathrm{U}$ & Buried; not recovered \\
\hline SOSMM-117 & 02-Jul-2003 & São Sebastião & 250 & $\mathrm{U}$ & Buried; not recovered \\
\hline CEEMAM-194 & 28-Jul-2003 & Guarujá & 170 & $\mathrm{U}$ & Skull in the MIPS collection \\
\hline CEEMAM-197 & 15-Aug-2003 & Bertioga & 318 & $\mathrm{~F}$ & Skull in the MIPS collection \\
\hline SOSMM-120 & 18-Aug-2003 & São Sebastião & 225 & M & Skull in the MIPS collection \\
\hline CEEMAM-205 & $25-$ Sep-2003 & Praia Grande & 200 & $\mathrm{U}$ & Skull in the MIPS collection \\
\hline CEEMAM-207 & $03-$ Oct- 2003 & Praia Grande & 250 & $\mathrm{U}$ & Skull in the MIPS collection \\
\hline CEEMAM-279 & 27-Dec-2006 & Guarujá & 150 & $\mathrm{~F}$ & Buried; not recovered \\
\hline CEEMAM-305 & 10-Jul-2007 & Guarujá & 287 & M & Live Stranding, Released alive \\
\hline SOSMM-172 & 13-Aug-2007 & São Sebastião & 290 & $\mathrm{U}$ & Buried; not recovered \\
\hline CEEMAM-321 & 30-Aug-2007 & Itanhaém & 300 & $\mathrm{U}$ & Buried; not recovered \\
\hline CEEMAM-334 & 26-Jan-2008 & Itanhaém & 260 & $\mathrm{U}$ & Skull in the MIPS collection \\
\hline
\end{tabular}

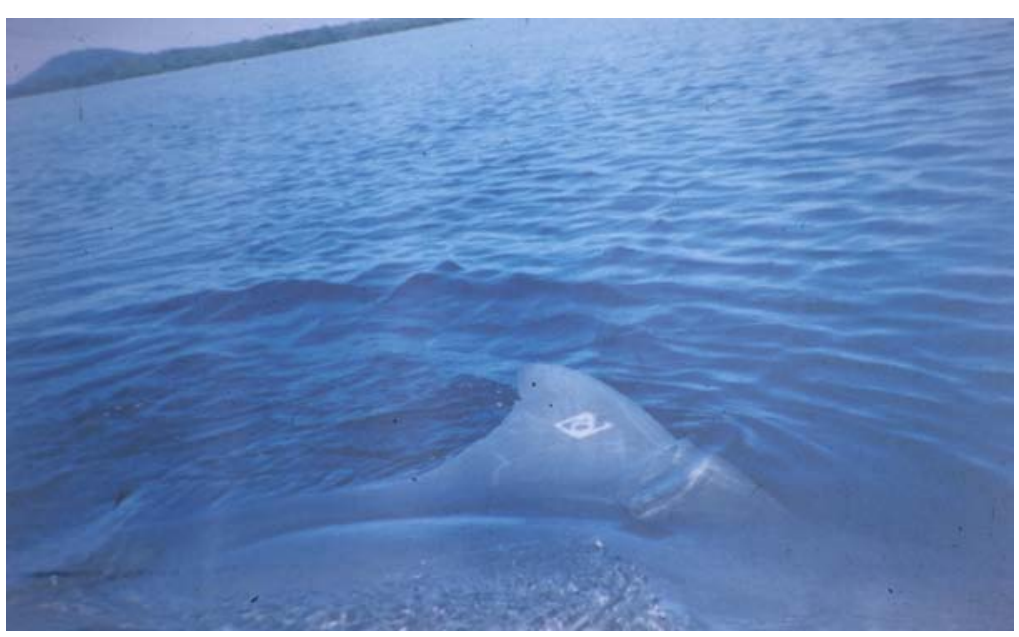

Fig. 9. Male bottlenose dolphin (Tursiops truncatus) named "Flipper" released from captivity in southern Brazil $\left(27^{\circ} \mathrm{S}\right)$ in 1993 and found in April 1994 in the estuary of Cananéia $\left(25^{\circ} \mathrm{S}\right)$. The Brazilian flag had been freeze-branded on its dorsal fin. Photo: Marcos Campolim. 
- Stenella frontalis (G. Cuvier, 1829): Atlantic spotted dolphins are commonly observed from $21^{\circ} \mathrm{S}$ to $33^{\circ} \mathrm{S}$ (ZERBINI et al., 2004; MORENO et al., 2005). Strandings are common in SP throughout the year and all along the coast, rendering a considerable amount of osteological material deposited mainly in the MZUSP, the MIPS, the PA and the SOSMM collections. SCUBA diving operators have been reporting sightings close to the following islands: Vitoria, Anchieta, Alcatrazes, Ilhabela, Couves and Queimada Grande.

- Stenella longirostris (Gray, 1828): The incidental capture of a spinner dolphin in fishing operations between SP and Rio de Janeiro was observed in January 1993 (SANTOS; DITT, in press). A few sightings have been observed in deeper waters by Zerbini et al. (2004)

- Stenella coeruleoalba (Meyen, 1833): Three records of the striped dolphin are known for the coast of SP. Rosas et al. (2002a) reported the first known account for this coast. It concerned a $244 \mathrm{~cm}$ long male washed ashore on Ilha Comprida on 14 February 1999. On 08 April 2008, a male without its peduncle and with an estimated length of $140+\mathrm{cm}$ was found dead at/on São Sebastião (SOSMM-179). It was buried but not recovered.

- Sotalia guianensis (Van Bénèden, 1864): Reports of sighted (Fig. 10) and beached Guiana dolphins are common all year round thoughout the length of the coast (see DE CARVALHO, 1963; SCHMIEGELOW, 1990; MONTEIRO-FILHO, 1995; GEISE; CERQUEIRA, 1999; SANTOS et al., 2001b; SANTOS; ROSSO, 2008). S. guianensis is the most common cetacean species seen along the SP coast, occurring in bays and estuaries. A resident population, which has been being studied since the 1990s, is to be found by the hundreds all year round in the Cananéia estuary (see MONTEIRO-FILHO, 1995; SANTOS; ROSSO, 2007; 2008). The only known case of a lone and sociable Guiana dolphin was described by Santos et al. (2000).

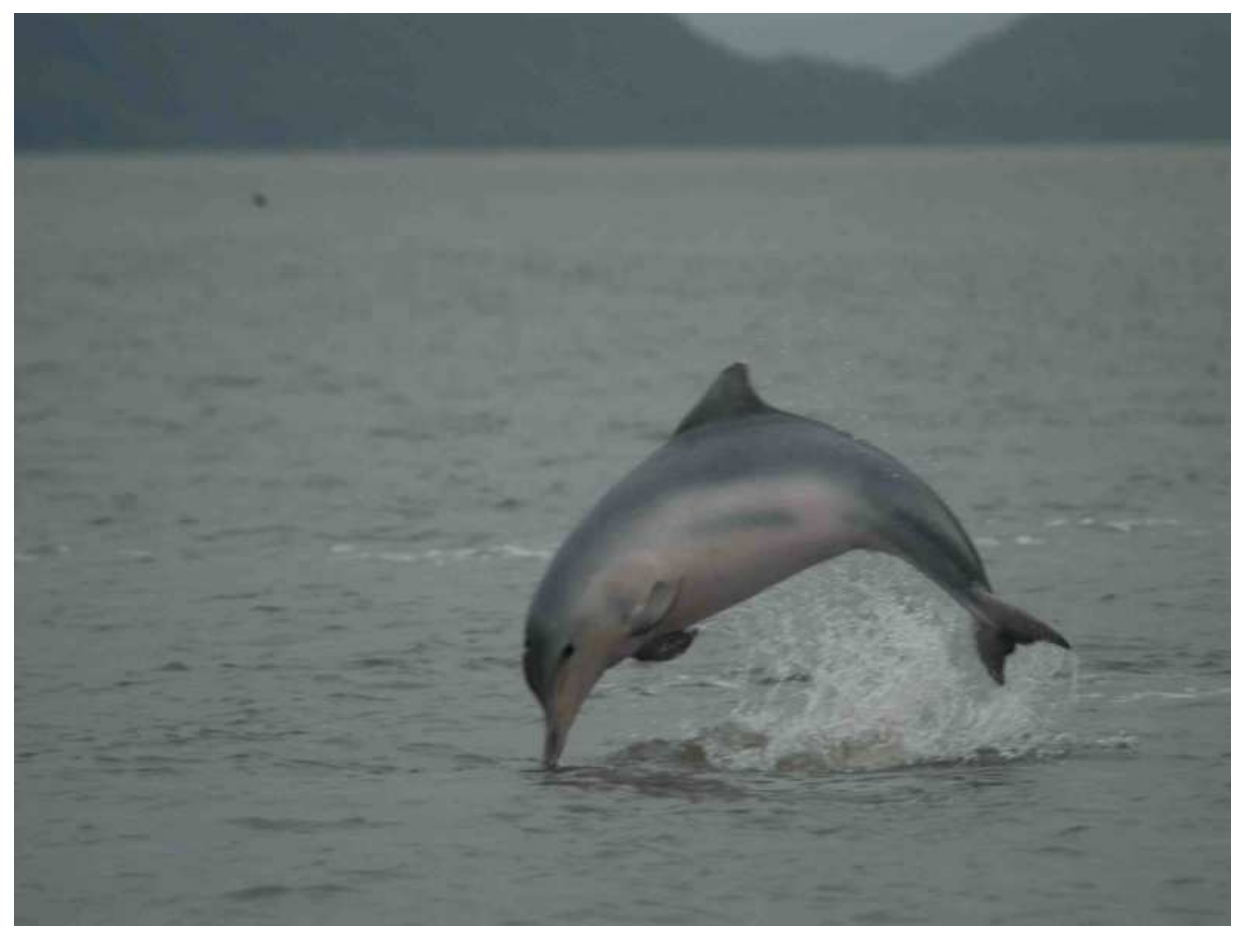

Fig. 10. Guiana dolphin (Sotalia guianensis) in the Cananéia estuary: the most commonly seen cetacean species throughout the SP coast. Photo: Marcos Santos. 
- Pontoporia blainvillei (Gervais and D'Orbigny, 1844): Live and dead beached Franciscana dolphins have been reported since the 1960s throughout the length of the coast (e.g. DE CARVALHO, 1961; SCHMIEGELOW, 1990; SANTOS et al., 2002b). Since the end of the 1990s, incidental captures have also been monitored (e.g. BERTOZZI; ZERBINI, 2002; ROSAS et al., 2002b). P. blainvillei can be found year-round in shallow coastal waters. Based on habitat and behavioral characteristics (CRESPO, 2002), sighting records are rare (e.g. SANTOS et al., 2007; 2009).

The peculiar features of its wide continental shelf, the influence of the SACW on prey abundance, the presence of 58 islands along the coast, the seasonal migration of baleen whales, and a highly productive estuarine area are likely to be the main factors affecting the records of cetacean distribution along the SP state coast. Based on the plentiful evidence reported in the present study, anthropogenetic factors such as incidental captures in fishing operations, habitat degradation, boat collisions (Fig. 11), the unsupervised approach of boats to observe whales and dolphins (Fig. 12) and contacts with swimmers must be added to the list of the main factors driving cetaceans to be washed ashore in the SP state coast.
Of the 86 living species currently recognized in the order Cetacea (JEFFERSON et al., 2008), 46 $(53 \%)$ have been reported at least once in Brazilian waters - whether as sightings or strandings (see IBAMA, 2001; PINEDO et al., 2001; PINEDO et al., 2002; SANTOS et al., 2003; SICILIANO; SANTOS, 2003; SOUZA et al., 2005; CABALLERO et al., 2007). A total of 29 species is listed by the present study for the coast of SP, representing $63 \%$ of all the species reported in Brazilian waters. Some species can be found all the year round (e.g. S. guianensis, $P$. blainvillei, $S$. frontalis, $T$. truncatus), as the local coastal waters are part of their known distribution range, whereas others have been observed only once (e.g. B. physalus, B. arnuxii, M. europaeus, M. mirus, $G$. macrorhynchus, $P$. crassidens, $L$. peronii), including strays from their known distribution areas, as well as species with known offshore preferences rarely sighted close to the shore or represented in strandings. Not only have the number of stranding records been increasing over the last 20 years, but also that of cetacean sightings, due to the increase in observation efforts all along the coast. As a consequence, additional records of previously unreported species with known distribution ranges overlapping the coast of SP, as well as other strays and offshore species, may soon be added to the list presented here.

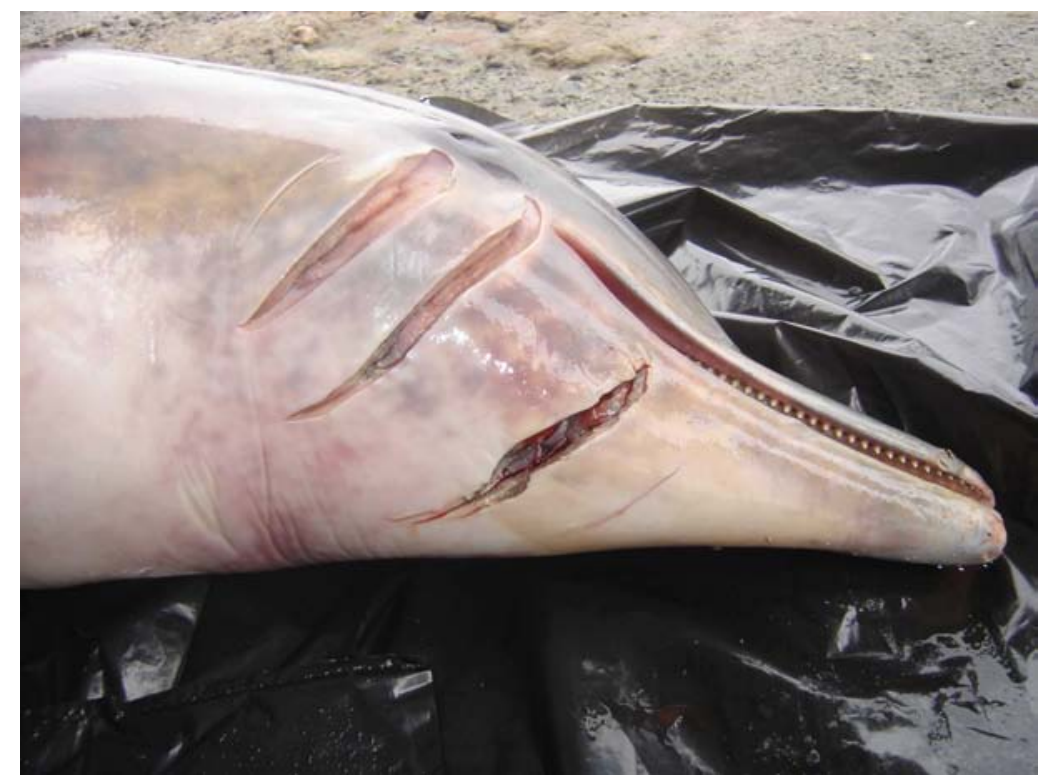

Fig. 11. Guiana dolphin (Sotalia guianensis) found dead in Santos with fresh propeller marks which represented the main cause of its death. Photo: André Vicente. 


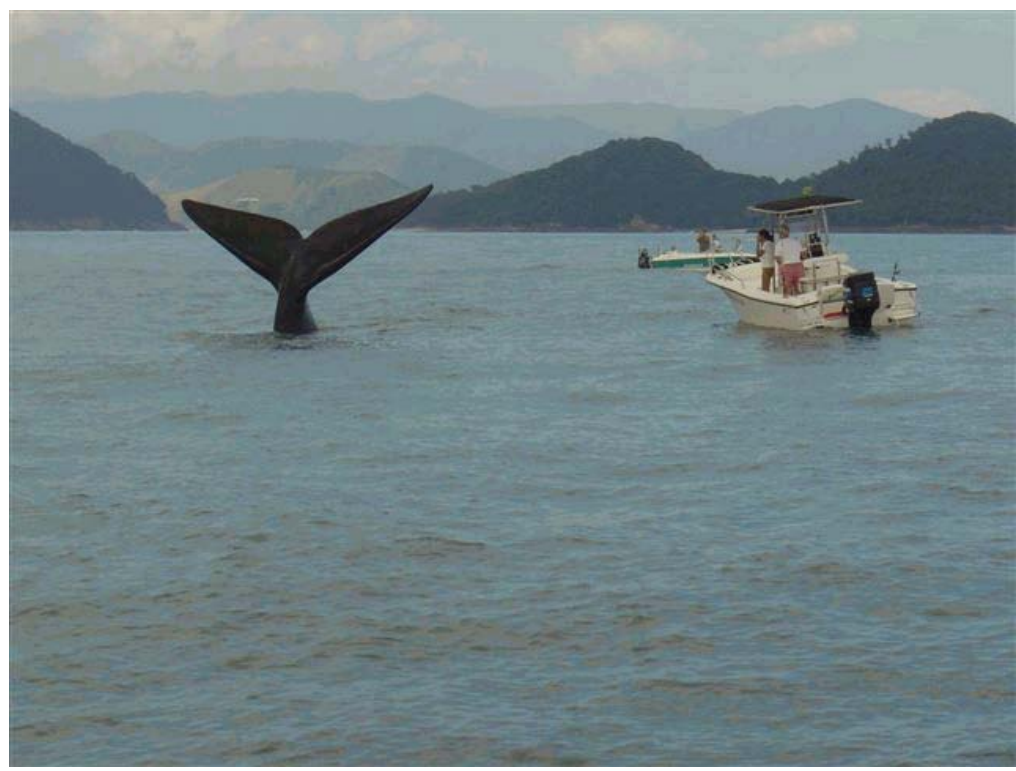

Fig. 12. Unsupervised approach to a female right whale (Eubalaena australis) in São Sebastião and which could lead to collision and trauma for both observers and whale. Photo: Marcos Morato.

Of the 13 currently known baleen whale species (JEFFERSON et al., 2008), 7 (54\%) have been listed for the coast of SP. All except Bryde's whales are known to migrate along coastal (e.g. right whales) or offshore waters off the coast of Brazil (e.g. fin, sei, minke whales) (see PAIVA; GRANJEIRO 1965; 1970; WILLIAMSON, 1975; LODI et al., 1996; ZERBINI et al., 1997; SANTOS et al., 2001a). Although strandings of Bryde's whales are reported year-round along the coast of Brazil (see ZERBINI et al., 1997; SICILIANO et al., 2004; present study), their migration patterns in the Southwestern Atlantic Ocean are still unknown. TERSHY et al. (1993) reported that B. edeni in the Gulf of California is primarily piscivorous, preying on Pacific sardines, Sardinops sagax. In other areas of the world, Bryde's whales are also known to be piscivorous (BEST, 1977). Brazilian sardines, Sardinella brasiliensis, are known to approach the coast to spawn in summer and fall (MATSUURA, 1979), when B. edeni has been regularly sighted close to several coastal islands off $\mathrm{SP}$; the feeding activities of this whale on sardines have also been reported (SICILIANO et al., 2004), thus giving evidence of prey influence on seasonal occurrence.

Of the 17 minke whale strandings reported, 6 have been confirmed as related to B. acutorostrata and 5 to $B$. bonaerensis. Common minke whales have a more coastal distribution than the Antarctic ones when migrating to lower latitudes (ZERBINI et al., 1996).
As a consequence, the possibility of their being involved in stranding events is greater. However, no difference in the proportions of the strandings of the two species has been observed. When migrating to the main breeding area on the coast of Brazil, located off Bahia state $\left(\sim 17^{\circ} \mathrm{S}\right)$, humpback whales traverse the region off the coast of SP (PIZZORNO et al., 1998). Juveniles and calves of the year were represented in greater numbers in the strandings observed in the present study. Juveniles may avoid reaching the breeding area in northern waters and calves of the year are usually recorded in strandings close to breeding areas.

Right whales are commonly sighted in winter and spring, when strandings have usually been reported (LODI et al., 1996; SANTOS et al., 2001a; (present study). Most strandings have involved calves which in a few cases have shown evidence of having been born in local waters. With the discovery of a main breeding area off southern Brazil $\left(\sim 27^{\circ} \mathrm{S}\right)$ (OTT et al., 2008), the recovery of the right whale population from past exploitation may be expanding the breeding area to include protected bays in southeastern Brazil. The northern coast of SP state has shallow protected bays which have been used by female-calf pairs during the last 20 years (see LODI et al., 1996; SANTOS et al., 2001a).

Stranding records in SP state of toothed whales with known offshore distribution - such as $P$. macrocephalus, $K$. breviceps, $K$. simus, Z. cavirostris, 
G. melas, G. macrorhynchus, $F$. attenuata, and $P$. crassidens - have been rare because of the width of the continental shelf (average of $c a .200 \mathrm{~km}$ ). This feature may be taken as one of the main reasons for the sympatric distribution of several delphinid species such as $T$. truncatus, $S$. bredanensis, $S$. frontalis, and D. capensis (see ZERBINI et al., 2004; MORENO et al., 2005; TAVARES et al., 2010), as well as for the higher incidence of these species' strandings. A few records have related to strays from their currently known range - such as B. arnuxii, M. europaeus and $L$. peronii. Two of these species are known to be found in higher latitudes (B. arnuxii and L. peronii) and $M$. europaeus is known to be found in lower latitudes. In winter, the stronger Falkland's/Malvinas Current may influence the approach of southern dwelling species to lower latitudes (MARTUSCELLI et al., 1995). The southern right-whale dolphin stranding was observed in the fall and that of the Arnoux beaked whale in winter. The two beaked whales quoted were washed ashore in an advanced state of decomposition, greatly limiting any detailed investigation of the possible causes of their strandings.

A considerable number of stranding and sighting records have concerned $T$. truncatus, $S$. frontalis, D. capensis and $O$. orca, coinciding with spring and summer months, when the SACW moves into the bottom layer over the continental shelf. This water mass carries nutrients to coastal waters and induces high primary production (SVERDRUP et al., 1942; CASTRO et al., 2006). A considerable, distinct group of fish species follows the movement of the SACW, approaching the coast within it (ROSSIWONGTSCHOWSKI; PAES, 1993). The delphinid species quoted probably approach the coast in the spring and summer months influenced by the concentration of food resources induced by the SACW.S. guianensis and P. blainvillei are the best known cetacean species on the SP coast. Although both species can be found in shallow waters yearround, our knowledge of $P$. blainvillei comes exclusively from studies of carcasses recovered after strandings and incidental captures (e.g. BERTOZZI; ZERBINI, 2002; SANTOS et al., 2002b; ROSAS et al.; 2002b). S. guianensis is the most common cetacean species found in Brazilian coastal and estuarine waters (FLORES; DA SILVA, 2009), providing the main approach to the study of small cetaceans in the wild.

Several of the species listed in this manuscript provide evidence of involvement, as bycatch, in fishing operations. Most of the cetacean

species known to be found in Brazilian waters have been reported as having been involved in incidental capture events (see SICILIANO, 1994; SANTOS;
DITT, in press). Based on their distribution which overlaps the main fishing ground, coastal species such as $S$. guianensis and $P$. blainvillei may be listed among those which are most threatened in terms of bycatch (SICILIANO, 1994). However, this threat must affect all the other cetacean species which are present on the wide continental shelf of the SP coast. As a consequence, the monitoring of fishing fleets along the coast is recommended so that an accurate scenario regarding incidental cetacean captures in time and space may be described for management and conservation purposes.

A common procedure adopted by most municipal administrations regarding cetacean strandings at the main coastal cities was observed. Dead specimens are usually buried or taken to garbage dumps in order to keep local beaches clean, and on the majority of occasions they have never been recovered. Several baleen and beaked whale specimens presented in this study have never been precisely identified because no biological evidence was available to confirm their species identity. Larger animals have usually attracted more attention from coastal inhabitants and the media. Recovering their osteological material is a tough task. The lack of adequate local experience to deal with strandings and the absence of natural history museums along the coast to keep valuable skeletons are the main barriers to the gathering of complete information on stranding events. Specimens have rarely been prepared for educational purposes; the complete baleen whale skeletons on exhibition in the MIPS and in the AG are exceptions to the rule. In the light of the historical data and the records presented, it is to be recommended that a network structure should be established to attend cetacean strandings, as well as to store the valuable biological material collected. As long as no such stranding network is established, important information on cetacean strandings will continue to be lost. Organized stranding networks, will surely enhance the gathering of precise and complete information on beached cetaceans (see Geraci; Lounsbury, 1993).

The Brazilian government has recently established a sanctuary for whales and dolphins in coastal waters (Federal Decree \#6,698; 17 December 2008), and a Marine Environmental Protected Area has been established throughout the length of the SP coast (State Decree \#53,527; 08 October 2008), thus reinforcing the need for investment in cetacean research and conservation. Surveys dedicated to cetacean sightings in SP coastal waters are unusual. The sighting of opportunistic occurrences is usually reported from platforms mainly used by SCUBA diving operators who exercise their activity on various islands along the coast. These platforms should, 
therefore, be better exploited by research groups as an important source for cetacean sighting records. Companies involved in gas and oil exploitation should also be contacted to optimize the use of their platforms in the near future. Oceanographic cruises involving interdisciplinary investigations in coastal and offshore waters should be recommended. It is also recommended that an on-line databank, allowing researchers to insert the baseline information of their annual stranding records, should be established, making further revisions of cetacean records, as well as any assessment of such events, an easier task. As emerging infectious diseases have been reported in cetaceans worldwide (VAN BRESSEM et al., 2009), it is important that all research groups should evaluate the health status of stranded marine mammals.

\section{ACKNOWLEDGEMENTS}

We wish to thank Alexandre C. Simonelli (FSP), Raimundo Rosa (TS), Daniela Gurgel, Renata Fernanda, Reginaldo Pupo (IL), José Valpereiro (Jornal Vale Paraibano), Sérgio L. Pompéia and Roney P. dos Santos (CETESB) who provided photographs and helped to access newspaper files. Alexandre Zerbini kindly helped with the identification of several baleen whales at lower taxa. The MIPS kindly stored the valuable osteological collection of the CEEMAM research group. Field support came from the Instituto Oceanográfico da Universidade de São Paulo (IO-USP), Universidade de Ribeirão Preto (UNAERP), Fundação Fernando Lee, SEMAM Santos and Guarujá, IBAMA-Santos, Osmar Correa (ESEC Tupinambás), Álvaro Migoto (CEBIMar), Nelson Dreaux (MIPS), Tânia Amaral (CEEMAM, in memoriam) and Ednilson da Silva (PA). We are indebted to the administrations of the following municipalities: Santos, São Vicente, Praia Grande, Mongaguá, Itanhaém, Peruíbe, Bertioga, Guarujá and São Sebastião. This survey was partially sponsored by the Cetacean International Society, the Whale \& Dolphin Conservation Society, WWF-Fundo Mundial para a Natureza, the Earthwatch Institute and Petrobras. M. Santos received grants from CAPES (M. Sc.: 1996-1998) and FAPESP (Ph. D.: 2000-2004; "Jovem Pesquisador": 2005-2009). S. Siciliano is the recipient of a fellowship ("Produtividade em Pesquisa") from CNPq. We wish also to thank the anonymous reviewers for their critical suggestions which contributed to the improvement of this manuscript. Júlia Oshima provided the map.

\section{REFERENCES}

BERTOZZI, C. P.; ZERBINI, A. N. Incidental mortality of franciscana (Pontoporia blainvillei) in the artisanal fishery of Praia Grande, São Paulo state, Brazil. Latin Am. J. aquatic Mamm., v. 1, n. 1, p. 153-160, 2002.

BESNARD, W. Considerações gerais em torno da região lagunar de Cananéia-Iguape I. Bolm Inst. Paul. Oceanogr. S.Paulo, v. 1, n. 1, p. 9-26, 1950.

BEST, P. B. Two allopatric forms of Bryde's whale of South Africa. Rept int. Whal. Commn, Special Issue, n. 1, p. 10-38. 1977.

CABALLERO, S.; TRUJILLO, F.; VIANNA, J.; GARRIDO, H. B.; MONTIEL, M. G.; PEDREROS, S. B.; MARMONTEL, M.; SANTOS, M. C. DE O.; ROSSIWONGTSCHOWSKI; SANTOS, M.; SANTOS, F.; BAKER, S. Taxonomic status of the genus Sotalia: species level ranking for Tucuxi (Sotalia fluviatilis) and Costero (Sotalia guianensis) dolphins. Mar. mamm. Sci., v. 23, n.2, p. 358-386, 2007.

CARVALHO, J. DE P. Sobre os balenopterídeos que frequentam a costa paulista. A Voz do Mar, v. 27, n. 161, p.181-184, 1938.

CARVALHO, J. DE P. Sobre a provável ocorrência da "baleia de Cuvier" no litoral de São Paulo. Rev. nac. Pesca, n. 10, v. 82, p. 8-11, 1969.

CASTELLO, H. P.; PINEDO, M. C. Southern right whales (Eubalaena australis) along the southern Brazilian coast. J. Mammal., n. 60, v. 2, p. 429-430, 1979.

CASTRO, B. M.; MIRANDA, L. B.; MIYAO, S. Y. Condições hidrográficas na plataforma continental ao largo de Ubatuba: variações sazonais e em média escala. Bolm Inst. oceanogr., São Paulo, n. 35, v. 2, p. 135$151,1987$.

CASTRO, B. M.; LORENZZETTI, J. A.; DA SILVEIRA, I. C. A.; MIRANDA, L. B. Estrutura termohalina e circulação na região entre o Cabo de São Tomé (RJ) e o Chuí (RS). In: ROSSI-WONGTSCHOWSKI, C. L. D. B.; MADUREIRA, L. S. (Ed.). O ambiente oceanográfico da plataforma continental e do talude na região sudeste-sul do Brasil. São Paulo: Editora da Universidade de São Paulo, p. 11-120, 2006.

CODESP. Port of Santos, Brazil - 100 years (1892-1992). Santos, SP: Companhia Docas do Estado de São Paulo (CODESP), 1992. 25 p. Special Issue.

CRESPO, E. A. Franciscana, Pontoporia blainvillei. In: PERRIN, W. F.; WÜRSIG, B.; THEWISSEN, J. G. M. (Ed.). Encyclopedia of marine mammals. San Diego, CA: Academic Press, p. 482-485, 2002.

DE CARVALHO, C. T. Stenodelphis blainvillei na costa meridional do Brasil, com notas osteológicas (Cetacea, Platanistidae). Rev. Bras. Biol., n. 21, v. 1, p. 443-454, 1961.

DE CARVALHO, C. T. Sobre um boto comum no litoral do Brasil. Rev. Bras. Biol., v. 23, n. 3, p. 263-276, 1963.

DE CARVALHO, C. T. Notas sobre Kogia breviceps (Cetacea, Physeteridae). Revta. Biol. trop., v. 14, n. 2, p. $169-181,1966$

DE CARVALHO, C. T. Ocorrência de mamíferos marinhos no Brasil. Bolm tec. Inst. Flor., São Paulo, v. 16, n. 1, p. $13-22,1975$

ELLIS, M. A baleia no Brasil colonial. São Paulo: Editora Melhoramentos, 1969. $235 \mathrm{p}$.

EMÍLSSON, I. The shelf and coastal waters off southern Brazil. Bolm Inst. oceanogr., S. Paulo, v. 11, n. 2, p. 101-112, 1961. 
FLORES, P. A. C; DA SILVA, V. M. F. Tucuxi and Guiana dolphin Sotalia fluviatilis and $S$. guianensis. In: PERRIN, W. F.; WÜRSIG, B.; THEWISSEN, J. G. M. (Ed.). Encyclopedia of marine mammals. San Diego, CA: Academic Press, p. 1188-1192, 2009.

GEISE, L.; GOMES, N.; CERQUEIRA, R. Behaviour, habitat use and population size of Sotalia fluviatilis (Gervais, 1853) (Cetacea, Delphinidae) in the Cananéia estuary region, São Paulo, Brazil. Rev. Bras. Biol., n. 59, v. 2, p. 183-194, 1999.

GERACI, J. R.; LOUNSBURY, V. J. Marine mammals ashore: A field guide for strandings. Texas A \& M Sea Grant Publication, 1993. 304 p.

HEYNING, J. E.; PERRIN, W. F. Evidence for two species of common dolphins (genus Delphinus) from the eastern north Pacific. Contr. Sci., nat. Hist. Mus. Los Angeles, n. 442, n. 1, p. 1-35, 1994.

IBAMA. Mamíferos aquáticos do Brasil: Plano de ação. Versão II. Brasilia, DF, Edições IBAMA, 2001. 96 p

JEFFERSON, T. A; WEBBER, M. A; PITMAN, R. L. (EDS). Marine mammals of the world: A comprehensive guide to their identification. London: Academic Press, London, 2008. 573 p.

LODI, L.; HETZEL, B. Orcinus orca (Cetacea; Delphinidae) em águas costeiras do Estado do Rio de Janeiro. Bioikos, v. 12, n. 1, p. 46-54, 1998.

LODI, L.; SICILIANO, S.; BELLINI, C. Ocorrências e conservação de baleias-francas-do-sul, Eubalaena australis, no litoral do Brasil. Papeis av. Zool., v. 39, n. 17, p. 307-328, 1996.

LUEDERWALDT, H. Os manguesaes de Santos. Rev. Mus. Paulista, v. II, p. 309-408, 1919.

MARTUSCELli, P.; MILANELO, M.; OLMOS, F. First record of Arnoux's beaked whale (Berardius arnuxii) and southern right-whale dolphin (Lissodelphis peronii) from Brazil. Mammalia, v. 59, n. 2, p. 274-275, 1995.

MATSUURA, Y. Contribuição ao estudo da estrutura oceanográfica da região sudeste entre Cabo Frio (RJ) e Cabo de Santa Marta Grande (SC). Cienc. Cult., S Paulo, v. 38, n. 8, p. 1439-1450, 1986.

MATSUURA, Y. Distribution and abundance of eggs and larvae of the Brazilian sardine, Sardinella brasiliensis, during 1974-1975 and 1975-1976 seasons. Bull. japan. Soc. Fish. Oceanogr., v. 34, n. 1, p. 1-12, 1979.

MONTEIRO-FILHO, E. L. A. Pesca interativa entre o golfinho Sotalia fluviatilis guianensis e a comunidade pesqueira da região de Cananéia. Bolm. Inst. Pesca, S Paulo, v. 22, n. 1, p. 15-23, 1995.

MOORE, S. E. Marine mammals as ecosystem sentinels. J. Mammal., v. 89, n. 3, p. 534-540, 2008.

MORENO, I. B.; ZERBINI, A.N.; DANILEWICZ, D.; SANTOS, M. C. DE O.; SIMÕES-LOPES, P. C.; LAILSON-BRITO JR., J.; AZEVEDO, A. Distribution and habitat characteristics of dolphins of the genus Stenella (Cetacea: Delphinidae) in the Southwest Atlantic Ocean. Mar. Ecol. Prog. Ser., v. 300, n. 1-2, p. 229-240, 2005.

OTT, P. H.; GROCH, K.; DANILEWICZ, D. Eubalaena australis (Desmoulins, 1822). In: MACHADO, A. B.M.; DRUMMOND, G. M.; ; PAGLIA, A. P. (Ed.). Livro vermelho da fauna brasileira ameaçada de
extinção.Brasilia, DF: Ministério do Meio Ambiente, v. 2, p. 802-804, 2008.

PAIVA, M. P.; GRANJEIRO, B. F. Biological investigations in the whaling seasons 1960-1963 of northeastern coast of Brazil. Arq. Est. Biol. Mar, n. 5, v. 1, p. 29-64, 1965.

PAIVA, M. P.; GRANJEIRO, B. F. Investigations in the whaling seasons 1964-1967 of northeastern coast of Brazil. Arq. Est. Biol. Mar, v. 10, n. 2, p. 111-26, 1970.

PINEDO, M. C.; LAMMARDO, M. P.; BARRETO; A. S. Review of Ziphius cavirostris, Mesoplodon grayi and Lagenodelphis hosei (Cetacea: Ziphiidae and Delphinidae) in Brazilian waters, with new records from southern Brazil. Atlântica, v. 23, n. 1, p. 67-76, 2001.

PINEDO, M. C.; BARRETO; A. S.; LAMMARDO, M. P.; ANDRADE, A. L. V.; GERACITANO, L. Northernmost records of the spectacled porpoise, Layard's beaked whale, Commerson's dolphin, and Peale's dolphin in the southwestern Atlantic Ocean. Aquat. Mamm., v. 28, n. 1, p. 32-37, 2002.

PIZZORNO, J. L. A.; LAÍlSON-BRITO JR., J.; DORNELES, P. R.; AZEVEDO, A. F.; GURGEL, I. M. G. Review of strandings and additional information on humpback whales, Megaptera novaeangliae, in Rio de Janeiro, southeastern Brazilian coast (1981-1997). Rept int. Whal. Commn., v. 48, p. 443-446, 1998.

RAMOS, R.; SICILIANO, S.; BOROBIA, M.; ZERBINI, A.; PIZZORNO, J.; FRAGOSO, A.; LAÍLSON-BRITO JR., J. \& AZEVEDO, A.; SIMÕES-LOPES, P.; SANTOS, M. C. DE O. A note on strandings and age of sperm whales (Physeter macrocephalus) on the Brazilian coast. J. Cet. Res. Manag., v. 3, n. 3, p. 321-327, 2001.

ROSAS, F. C. W.; MONTEIRO-FILHO, E. L. A.; MARIGO, J.; SANTOS, R. A.; ANDRADE, A. L. V.; RAUTENBERG, M.; OLIVEIRA, M. R.; BORDIGNON, M. O. The striped dolphin, Stenella coeruleoalba (Cetacea, Delphinidae), on the coast of São Paulo state, southeastern Brazil. Aquat. Mamm., v. 28 , n. 1, p. 60-66, 2002a.

ROSAS, F. C. W.; MONTEIRO-FILHO, E. L. A.; OLIVEIRA, M. R. Incidental catches of franciscana (Pontoporia blainvillei) on the southern coast of São Paulo state and the coast of Paraná state, Brazil. Latin Am. J. aquat. Mamm., v. 1, n. 1, p. 161-168, 2002b.

ROSSI-WONGTSCHOWSKI, C. L. D. B.. Produção de peixes demersais na região sudeste. In: ROSSIWONGTSCHOWSKI, C. L. D. B.; MADUREIRA, L. S. (Eds). O Ambiente Oceanográfico da Plataforma Continental e do Talude na Região Sudeste-Sul do Brasil. Editora da Universidade de São Paulo, SP, p. 11120, 2006.

ROSSI-WONGTSCHOWSKI, C. L. D. B.; PAES, E. T. Padrões espaciais e temporais da comunidade de peixes demersais do litoral norte do Estado de São Paulo Ubatuba, Brasil. Publçao esp. Inst. oceanogr., Sao Paulo, v. 10, p. 169-188, 1993.

SANTOS, M. C. DE O. Lone, sociable bottlenose dolphin in Brazil: human fatality and management. Mar. Mamm. Sci., v. 13, n. 2, p. 355-356, 1997. 
SANTOS, M. C. DE O.; ROSSO, S. Ecological aspects of marine tucuxi dolphins (Sotalia guianensis) based on group size and composition in the Cananéia estuary, southeastern Brazil. Latin Am. J. aquat. Mamm., v. 6, n. 1, p. 71-82, 2007.

SANTOS, M. C. DE O.; ROSSO, S. Social organization of marine tucuxi dolphins, Sotalia guianensis, in the Cananéia estuary of southeastern Brazil. J. Mamm., v. 89 , n. 2, p. 347-355, 2008

SANTOS, M.C. DE O.; DA SILVA, E. Records of a male killer whale (Orcinus orca) in southeastern Brazil. Braz. J. Oceanogr., v. 57, n. 1, p. 65-68, 2009.

SANTOS, M. C. DE O.; DITT, E. H. Incidental capture of a spinner dolphin, Stenella longirostris (Gray, 1828), in a gillnet set for sharks off the Brazilian southeast coast. Latin Am. J. aquat. Mamm., v. 6, n. 2. In press.

SANTOS, M.C. DE O., ROSSO, S., SICILIANO, S. ZERBINI, A., ZAMPIROLLI, E., VICENTE, A.F.; ALVARENGA, F. Behavioral observations of the marine tucuxi dolphin (Sotalia fluviatilis) in São Paulo estuarine waters, Southeastern Brazil. Aquat. Mamm., v. 26, n. 4: 260-267, 2000

SANTOS, M. C. DE O.; SICILIANO, S.; PACHECO, S.; PIZZORNO, J. L. A. Occurrence of southern right whales, Eubalaena australis, along southeastern Brazilian coast. J. Cet. Res. Manag., Special Issue 2, p. 153-156, 2001a.

SANTOS, M.C. DE O., ACUÑA, L.B.; ROSSO, S. Insights on site fidelity and calving intervals of the marine tucuxi dolphin (Sotalia fluviatilis) in south-eastern Brazil. J. mar. biol. Ass. U. K., v. 81, n. 6; 1049-1052, 2001b.

SANTOS, M. C. DE O.; ROSSO, S.; RAMOS, R.M.A Common dolphins (genus Delphinus) in Southeastern Brazil. Z. Fischkd. (Mamm. Biol.), v. 67, n. 1, p. 47-50, 2002a.

SANTOS, M. C. DE O.; VICENTE, A. F. C; ZAMPIROLLI, E.; ALVARENGA, F. S.; SOUZA, S.P. Records of franciscana (Pontoporia blainvillei) from the coastal waters of São Paulo state, Southeastern Brazil. Latin Am. J. aquatic Mamm., v. 1, n. 1, p. 169-174, 2002b.

SANTOS, M. C. DE O., ZAMPIROLLI, E., VICENTE, A. F. V.; ALVARENGA, F. A Gervais' beaked whale (Mesoplodon europaeus) washed ashore in southeastern Brazil: extra limital record? Aquat. Mamm., v. 29, n. 3, p. 404-410, 2003.

SANTOS, M. C. DE O.; PACÍFICO, E. DOS S. GONÇALVES, M. F. Unusual record of franciscana dolphins (Pontoporia blainvillei) in inner waters of the Cananéia estuary, southeastern Brazil. Latin Am. J. Aquatic Mamm., v. 6, n. 1, p. 117-119, 2007.

SANTOS, M. C. DE O. ; OSHIMA, J. E. F.; DA SILVA, E. Sightings of franciscana dolphins (Pontoporia blainvillei): the discovery of a population in the Paranaguá Estuarine Complex. Braz. J. Oceanogr., v. 57, n. 1, p. 57-63, 2009.

SAWAYA, P. Sobre o "Piolho da Baleia". Bolm Fac. Fil. Cien. Let. USP, S. Paulo, Zoologia, v. 2, 197-248, 1938.

SCHAEFFER-NOVELLI, Y., MESQUITA, H. DE S. L.; CINTRÓN-MOLERO, G. The Cananéia lagoon estuarine system, São Paulo, Brazil. Estuaries, v. 13, n. 2, p. 193-203, 1990
SCHMIEGELOW, J. M. M. Estudo sobre os cetáceos odontocetos em praias da região entre Iguape (SP) e baía de Paranaguá (PR) $\left(2^{\circ} 42^{\prime} \mathrm{S}-2^{\circ} 28^{\prime} \mathrm{S}\right)$ com especial referência a Sotalia fluviatilis (Gervais, 1853) (Delphinidae). 149 p. Master's Thesis, Instituto Oceanográfico, Universidade de São Paulo, São Paulo, 1990.

SCHMIEGELOW, J. M. M.; PAIVA FILHO, A. M. First record of the short-finned pilot whale Globicephala macrorhynchus Gray, 1846, for the Southeastern Atlantic. Mar. Mamm. Sci., v. 5, n. 4, p. 387-391, 1989.

SMA. Mapeamento dos ecossistemas costeiros do Estado de São Paulo. São Paulo, SP: Secretaria do Meio Ambiente, CETESB, 1998. 108 p.

SICILIANO, S. Review of small cetaceans and fisheries interactions in coastal waters of Brazil. Rept int. Whal. Commn., Special Issue, n. 15, p. 241-250, 1994.

SICILIANO, S.; SANTOS, M. C. DE O. On the occurrence of the Arnoux's beaked whale (Berardius arnuxii) in Brazil. J. mar. biol. Ass. U. K., v. 83, n. 4, p. 887-888, 2003

SICILIANO, S., SANTOS, M. C. DE O., VICENTE, A. F. C., ALVARENGA, F. S., ZAMPIROLLI. E., LAÍLSONBRITO, J., AZEVEDO, A. F.; PIZZORNO, J. L. Strandings and feeding records of Bryde's whales (Balaenoptera edeni) in south-eastern Brazil. J. mar. biol. Ass. U. K., v. 84, n. 4, p. 857-859, 2004.

SOUZA, S. P.; SICILIANO, S.; CUENCA, S.; SANCTIS, B. A True's beaked whale (Mesoplodon mirus) on the coast of Brazil: adding a new beaked whale species to the Western Tropical Atlantic and South America. Latin Am. J. aquat. Mamm., v. 4, n. 2, p. 129-136, 2005.

STRAMMA, L. The Brazil Current transport south of $23^{\circ} \mathrm{S}$. Deep Sea Res., v. 36, n. 4A, p. 639-646, 1989.

SVERDRUP, H. U.; JOHNSON, M. W.; FLEMING, R. H. The Oceans: Their Physics, Chemistry, and general Biology. New York: Prentice Hall, 1942. 1087p.

TAVARES, M.; MORENO, I. B.; SICILIANO, S.; RODRÍGUEZ, D.; SANTOS, M. C. DE O.; LAILSONBRITO, J.; FABIÁN, M. Biogeography of common dolphins (genus Delphinus) in the South-western Atlantic Ocean. Mamm. Rev., v. 40, n. 1, p.40-64, 2010. (In press)

TERSHY, B. R.; ACEVEDO-GUTIERREZ, A.; BREEZE, D.; STRONG, C. S. Diet and feeding behavior of fin and Bryde's whales in the Central Gulf of California, Mexico. Revta Invest. Cient., v. 1, n. 1, 3138, 1993.

TOWNSEND, C. H. The distribution of certain whales as shown by logbook records of American whaleships. Zoologica-NY, v. 19, n. 1, p. 2-50, 1935.

VAN BRESSEM, M-F; RAGA, J. A.; DI GUARDO, G.; JEPSON, P. D.; DUIGNAN, P.; SIEBERT, U.; BARRET, T.; SANTOS, M. C. DE O.; MORENO, I. B.; SICILIANO, S.; AGUILAR, A., WAEREBEEK, K. V. Emerging infectious diseases in cetaceans worldwide and the possible role of environmental stressors. Dis. aquat. Org., v. 86, n. 2, p. 143-157, 2009.

WILLIAMSON, G. R. Minke whales off Brazil. Sci. Rep. Whales Res. Inst., n. 27, p. 37-59, 1975. 
ZERBINI, A. N.; SANTOS, M.C. DE O. First record of the pygmy killer whale Feresa attenuata (Gray, 1874) for the Brazilian coast. Aquat. Mamm., v. 23, n. 2, p. 105109, 1997

ZERBINI, A. N.; SECCHI, E. R.; SICILIANO, S.; SIMÕESLOPES, P. C. The dwarf form of the minke whale, Balaenoptera acutorostrata Lacépède, 1804, in Brazil. Rept Int. Whal. Commn, v. 46, p. 333-340, 1996.

ZERBINI, A. N.; SECCHI, E. R.; SICILIANO, S.; SIMÕESLOPES, P. C. A review of the occurrence and distribution of whales of the genus Balaenoptera along the Brazilian coast. Rep. Int. Whal. Commn., v. 47, p. 407-417, 1997.
ZERBINI, A. N.; SECCHI, E. R.; BASSOI, M.; DALLA ROSA, L.; HIGA, A.; DE SOUZA, L.; MORENO, I. B.; MÖLLER, L. M.; CAON, G. Distribuição e abundância relativa de cetáceos na Zona Econômica Exclusiva da região sudeste-sul do Brasil. São Paulo: Instituto Oceanográfico-USP, 2004. Série Documentos REVIZEE Score Sul, 40 p.

(Manuscript received 20 March 2009; revised 05 May 2009; accepted 13 July 2009)

\section{APPENDIX I}

List of institutions surveyed for cetacean data in SP state, and in which biological material has been deposited. Abbreviations used throughout the manuscript are presented.

\begin{tabular}{|c|c|}
\hline Institutions & Abbreviations \\
\hline Aquário do Guarujá & AG \\
\hline Aquário Municipal de Santos & AMS \\
\hline Centro de Biologia Marinha da Universidade de São Paulo & CEBIMar \\
\hline Centro de Estudo de Encalhes de Mamíferos Marinhos - Santos & CEEMAM \\
\hline Companhia de Tecnologia de Saneamento Básico - São Paulo & CETESB \\
\hline Fundação Museu de História, Pesquisa e Arqueologia do Mar & FUNDAMAR \\
\hline Instituto Terra e Mar & ITM \\
\hline Museu de Zoologia da Universidade de São Paulo & MZUSP \\
\hline Museu do Instituto de Biociências da Universidade de São Paulo & MIBUSP \\
\hline Museu do Instituto de Pesca de Santos & MIPS \\
\hline Museu do Mar de Santos & MMS \\
\hline Newspaper File: A Tribuna de Santos & TS \\
\hline Newspaper File: Agência O Estado & $\mathrm{AE}$ \\
\hline Newspaper File: Folha de São Paulo & FSP \\
\hline Newspaper File: Imprensa Livre de São Sebastião & IL \\
\hline Projeto Atlantis & PA \\
\hline Projeto Tartarugas Marinhas - Ubatuba office & Projeto TAMAR \\
\hline Serviço Social do Comércio de São Paulo & SESC \\
\hline
\end{tabular}

